OPEN ACCESS

Edited by:

Frank Bernhard

Goethe-Universität Frankfurt am Main,

Germany

Reviewed by:

Bernard Mouillac,

INSERM, France

Alexei Yeliseev,

National Institutes of Health (NIH),

United States

${ }^{*}$ Correspondence:

Annette G. Beck-Sickinger abeck-sickinger@uni-leipzig.de

Specialty section:

This article was submitted to Translational Pharmacology, a section of the journal

Frontiers in Pharmacology

Received: 25 November 2018

Accepted: 11 February 2019

Published: 01 March 2019

Citation:

Kögler LM, Stichel J, Kaiser A and Beck-Sickinger AG (2019) Cell-Free Expression and Photo-Crosslinking of the Human Neuropeptide $Y_{2}$ Receptor. Front. Pharmacol. 10:176.

doi: 10.3389/fphar.2019.00176

\section{Cell-Free Expression and Photo-Crosslinking of the Human Neuropeptide $Y_{2}$ Receptor}

\author{
Lisa Maria Kögler, Jan Stichel, Anette Kaiser and Annette G. Beck-Sickinger* \\ Institute of Biochemistry, Faculty of Life Sciences, Leipzig University, Leipzig, Germany
}

G protein-coupled receptors (GPCRs) represent a large family of different proteins, which are involved in physiological processes throughout the entire body. Furthermore, they represent important drug targets. For rational drug design, it is important to get further insights into the binding mode of endogenous ligands as well as of therapeutic agents at the respective target receptors. However, structural investigations usually require homogenous, solubilized and functional receptors, which is still challenging. Cell-free expression methods have emerged in the last years and many different proteins are successfully expressed, including hydrophobic membrane proteins like GPCRs. In this work, an Escherichia coli based cell-free expression system was used to express the neuropeptide $Y_{2}$ receptor $\left(Y_{2} R\right)$ for structural investigations. This GPCR was expressed in two different variants, a C-terminal enhanced green fluorescent fusion protein and a cysteine deficient variant. In order to obtain soluble receptors, the expression was performed in the presence of mild detergents, either Brij-35 or Brij-58, which led to high amounts of soluble receptor. Furthermore, the influence of temperature, $\mathrm{pH}$ value and additives on protein expression and solubilization was tested. For functional and structural investigations, the receptors were expressed at $37^{\circ} \mathrm{C}, \mathrm{pH} 7.4$ in the presence of $1 \mathrm{mM}$ oxidized and $5 \mathrm{mM}$ reduced glutathione. The expressed receptors were purified by ligand affinity chromatography and functionality of $Y_{2} R$ _cysteine_deficient was verified by a homogenous binding assay. Finally, photo-crosslinking studies were performed between cell-free expressed $Y_{2} R$ _cysteine_deficient and a neuropeptide $Y$ (NPY) analog bearing the photoactive, unnatural amino acid $p$-benzoyl-phenylalanine at position 27 and biotin at position 22 for purification. After enzymatic digestion, fragments of crosslinked receptor were identified by mass spectrometry. Our findings demonstrate that, in contrast to $Y_{1} R$, NPY position 27 remains flexible when bound to $Y_{2} R$. These results are in agreement with the suggested binding mode of NPY at $Y_{2} R$.

Keywords: cell-free, human $Y_{2}$ receptor, photo-crosslinking, G protein-coupled receptors, neuropeptide $Y$

Abbreviations: 5(6)-TAMRA, 5(6)-carboxytetramethylrhodamine; Ahx, 6-amino-hexanoic acid; ATP, adenosine-5'triphosphate; Bpa, p-benzoyl-phenylalanine; Brij-35, polyoxyethylene(23)laurylether; Brij-58, polyoxyethylene(20)cetylether; BSA, bovine serum albumin; CECF, continuous exchange cell-free; Chaps, 3-[(3-cholamidopropyl)dimethylammonio]1-propansulfonat; CHS, cholesteryl hemisuccinate; CTP, cytidine-5'-triphosphate; Da, dalton; DDM, $n$-dodecyl $\beta$-D-maltoside; GSH, L-glutathione reduced; GSSG, L-glutathione oxidized; GTP, guanosine-5'-triphosphate; HEPES, 2[4-(2-hydroxyethyl)piperazin-1-yl] ethanesulfonic acid; IPTG, isopropyl $\beta$-D-1-thiogalactopyranoside; MALDI-ToF, matrixassisted laser desorption ionization time of flight; MS, mass spectrometry; NMR, nuclear magnetic resonance; NPY, neuropeptide Y; PEG, polyethylene glycol; Photo ${ }^{27}$-NPY, $\left[\mathrm{K}^{22}\left[(\mathrm{Ahx})_{2}\right.\right.$-biotin $\left.] \mathrm{Bpa}^{27}\right] \mathrm{NPY}$; PYY, peptide YY; RM, reaction mix; TM, transmembrane helix; tRNA, transfer ribonucleic acid; UTP, uridine- $5^{\prime}$-triphosphate; $\mathrm{Y}_{\mathrm{x}} \mathrm{R}$, neuropeptide $\mathrm{Y}$ receptor type $\mathrm{x}$. 


\section{INTRODUCTION}

G protein-coupled receptors (GPCR) are involved in the regulation of processes throughout the whole body and are therefore potential pharmaceutical targets. In 2017, about 35\% of all approved drugs used GPCRs as targets and still, there is huge potential left. With about 800 members, these proteins are the largest family of integral membrane proteins, and only 134 of them are targeted by pharmaceuticals by now (Sriram and Insel, 2018). In order to identify new drugs, new GPCR targets can be approached. Another concept is to find compounds for the fine-tuning of the GPCR signaling, which provides the opportunity to add other dimensions of regulation besides "on" or "off." The rational design of novel drug compounds requires detailed knowledge of the binding pocket as well as the dynamic processes GPCRs undergo during activation. However, direct structural investigations of GPCRs remain challenging owing to their hydrophobicity and structural flexibility, since GPCRs adapt many distinct conformations in the basal, as well in the active state (Katritch et al., 2013; Venkatakrishnan et al., 2013; Manglik et al., 2015; Latorraca et al., 2017).

X-ray crystallography and NMR spectroscopy are commonly used for the investigations of proteins. Until 2017, crystal structures of more than 30 different GPCRs have been solved in different activation states as reviewed by Xiang et al. (2016) and Lee et al. (2018). These structures, solved in complex with agonists, antagonists, G proteins, arrestins or stabilizing proteins, give insights into the mechanisms underlying GPCR activation and their conformations in inactive or active states. A drawback of crystallization is that only one conformation at a time can be captured, giving a good state-of-the-art picture, but conformations with short half-life are often missed.

To fill this gap, mass spectrometry (MS) based structural investigations can be performed complementary to the classical protein structural methods. One approach is the combination of crosslinking strategies with MS, which can provide information about interaction partners or can be used to map interaction surfaces, as recently reviewed (Nguyen et al., 2018; Seidel and Coin, 2018; Sinz, 2018). In contrast to X-ray crystallography or NMR spectroscopy, only low quantities of protein are needed for the identification of crosslinking regions by MS. Furthermore, structural information is gained at physiological $\mathrm{pH}$ and reflects the native protein conformation in solution. Only minor limitations in the size of the target proteins are found for MS, because the cross-linked complexes are usually enzymatically digested before MS analysis.

With increasing application of crosslinking, more crosslinking agents are available, providing different reactivity and specificity. These include homobifunctional crosslinkers, "zero-length" chemical crosslinkers, MS cleavable crosslinker and photo-crosslinker (Sinz, 2006; Manglik et al., 2015; Hage et al., 2017; Sinz, 2017).The latter are chemically inert compounds, which, upon irradiation with UV light, form reactive intermediates that can react with adjacent molecules to form covalent bonds (Weber and Beck-Sickinger, 1997). Among the most frequently used photo-reactive groups are benzophenones moieties, phenyl- and alkyl-diazirines and phenyl-azides as reviewed several times (Preston and Wilson, 2013; Sumranjit and Chung, 2013; Smith and Collins, 2015).The benzophenone moiety can be site-specifically inserted into proteins and peptides by using Bpa, an unnatural amino acid, and several techniques including solid-phase peptide synthesis (SPPS) (Kauer et al., 1986), expansion of the genetic code (Chin et al., 2002, 2003; Hino et al., 2005) or semi-synthetic approaches (David and Beck-Sickinger, 2007). After UV irradiation, the benzophenone moiety is able to form a reactive triplet ketyl biradical, whose oxygen is able to abstract hydrogens from weak $\mathrm{C}-\mathrm{H}$-bonds in a hydrophobic environment resulting in ketyl and alkyl radicals. These radicals then combine to form a C-C bond (Preston and Wilson, 2013). One drawback of MS-based structural investigations is the need for high quality MS data, which means that the protein of interest must be available in a homogenous and functional form.

Different strategies have been developed to address this issue and most cross-linking approaches are performed with GPCRs expressed in eukaryotic cells. To obtain GPCRs in a more defined environment and in higher amounts recombinant expression can be performed in hosts like insect, mammalian or prokaryotic cells (Shukla et al., 2015). While the production in insect and mammalian hosts requires more complex growth media, the growth of the cells is slower and is in general more expensive. The expression in prokaryotic cells mostly leads to the accumulation of GPCRs in inclusion bodies. This requires time-consuming resolubilization, purification and refolding steps to achieve functional receptors. When considering photo-crosslinking with subsequent analysis by matrix-assisted laser desorption ionization time of flight (MALDI-ToF) MS it is additionally favorable to avoid post-translational modifications, which usually leads to more heterogeneous protein samples and further complicates the interpretation of the results.

An alternative approach for the production of soluble, homogenous GPCRs are cell-free (CF) expression systems. Due to their open nature, these systems allow a directed optimization of the expression conditions with only minor limitations toward the protein production itself. The expression can be completely guided toward the expression of the protein of interest, which includes the enhancement of expressed protein, as well as the co-translational addition of protein stabilizers like detergents or lipids (Bernhard and Tozawa, 2013) and the adjustment of the redox conditions (Bundy and Swartz, 2011; Michel and Wüthrich, 2012; Proverbio et al., 2013). Furthermore, CF approaches offer a high potential for the efficient incorporation of unnatural amino acids (Staunton et al., 2006; Bundy and Swartz, 2010; Hong et al., 2014), without limitations due to toxicity or lacking transport to the cell membrane.

The NPY receptor family consists of four rhodopsin-like GPCRs in humans (Pedragosa-Badia et al., 2013), which are potential targets for the treatment of diverse diseases including metabolic diseases (Yi et al., 2018), cardiovascular diseases (Tan et al., 2018), as well as certain cancer types (Li et al., 2015; Tilan and Kitlinska, 2016) and disorders of the central nervous system (Duarte-Neves et al., 2016; Gøtzsche and Woldbye, 2016; Reichmann and Holzer, 2016; Robinson and Thiele, 2017). The endogenous ligand NPY binds to the $Y_{1} R$, the $Y_{2} R$ and the 
$\mathrm{Y}_{5} \mathrm{R}$ with high affinities, besides their relatively low sequence similarity (Brothers and Wahlestedt, 2010). It adopts diverse binding modes on the different NPY receptor subtypes, where it produces partially adverse effects. The binding mode of NPY to $\mathrm{Y}_{2} \mathrm{R}$ has been intensively studied by nuclear magnetic resonance (NMR) spectroscopy of recombinantly expressed and in vitro refolded receptor (Schmidt et al., 2009; Schmidt et al., 2017)in combination with mutagenesis studies and molecular modeling (Kaiser et al., 2015).

In this study we describe the soluble cell-free expression of two variants of the $\mathrm{Y}_{2} \mathrm{R}$, C-terminally coupled to a fluorescent protein $\left(\mathrm{Y}_{2} \mathrm{R} \_\mathrm{eGFP}\right)$, as well as a cysteine minimized variant ( $\mathrm{Y}_{2} \mathrm{R} \_$cysteine_deficient). We used an Escherichia coli (E. coli) based CF expression system and optimized it for receptor expression and solubilization. Active receptors were purified by ligand affinity chromatography. We furthermore performed a homogenous binding assay with the solubilized $\mathrm{Y}_{2} \mathrm{R}$ _cysteine_deficient to prove functionality. Photo-crosslinking studies were performed between $\mathrm{Y}_{2}$ R_cysteine_deficient and an NPY analog, containing Bpa at position 27 and biotin at position 22, and the results were compared to the known binding mode of NPY(13-36) to $\mathrm{Y}_{2} \mathrm{R}$ (Kaiser et al., 2015).

\section{MATERIALS AND METHODS}

\section{Peptide Synthesis}

Rink amide resin (4-(2,4-dimethoxyphenyl-Fmocaminomethyl)-phenoxy, $15 \mu \mathrm{mol}$ scale, loading $0.69 \mathrm{mmol} / \mathrm{g}$ ) was obtained from Iris Biotech (Marktredwitz, Germany), and NovaSyn TGR $\mathrm{R}$ resin (15 $\mu \mathrm{mol}$ scale, loading $0.18 \mathrm{mmol} / \mathrm{g}$ ) from Merck KGaA (Darmstadt, Germany). 9Fluorenylmethoxycarbonyl (Fmoc)- and tert-butyloxycarbonylprotected amino acids were purchased from Orpegen OPC (Heidelberg, Germany), Iris Biotech, and Sigma-Aldrich (Taufkirchen, Germany). Orthogonally 1-(4,4-dimethyl-2,6dioxocyclohexyl-idene)ethyl (Dde) protected amino acid Fmoc-Lys(Dde)-OH, as well as 6-(Fmoc-amino)-hexanoic acid (Ahx) and Fmoc-Bpa-OH, 1-[Bis(dimethylamino)methylene]-1H-1,2,3-triazolo[4,5-b]pyridi-nium 3-oxide hexafluorophosphate (HATU), 1-hydroxybenzotriazole (HOBt), ethyl2-cyano-2-(hydroxyimino)acetate (Oxyma), and $N, N^{\prime}$ diisopropylcarbodiimide (DIC) were purchased from Iris Biotech. Biotin, N,N-diisopropylethylamine (DIPEA), hydrazine, piperidine, 1,2-ethanedithiol (EDT), thioanisole (TA), and trifluoroacetic acid (TFA) were obtained from Sigma-Aldrich and 5(6)-TAMRA Novabiochem ${ }^{\circledR}$ from Merck KGaA. Acetonitrile (ACN) was from VWR (Darmstadt, Germany), dimethylformamide (DMF) and dichloromethane (DCM) were obtained from Biosolve (Valkenswaard, Netherlands), and p-thiocresol from Alfa Aesar (Ward Hill, MA, United States).

Porcine NPY (YPSKPDNPGEDAPAEDLARYYSALRHYINLI TRQRY- $\mathrm{NH}_{2}$ ) and analogs were synthesized by a combination of automated and manual SPPS on an automated multiple peptide synthesis robot system (Syro, MultiSynTech, Bochum, Germany), using Fmoc/tBu strategy in $15 \mu \mathrm{mol}$ scale as previously described
(Pedragosa-Badia et al., 2014). The porcine variant of NPY, which contains a single exchange at position 17 (M17L), was used due to its increased solubility and stability. The porcine NPY possesses affinity and signaling properties identical to the human NPY. It will be following termed NPY. NPY, biotin-(Ahx $)_{2}-\mathrm{NPY}$, and 5(6)-TAMRA-Ahx(5-24)NPY were synthesized on Rink amide resin and $\left[\mathrm{K}^{22}\left[(\mathrm{Ahx})_{2}\right.\right.$-biotin $\left.] \mathrm{Bpa}^{27}\right] \mathrm{NPY}\left(\right.$ Photo $\left.^{27}-\mathrm{NPY}\right)$ on a NovaSyn TGR R resin to obtain C-terminally amidated peptides.

All manual coupling reactions were performed at room temperature under constant shaking over night. For manual coupling of Ahx and Bpa 5 eq. of the respective Fmoc protected amino acid, 5 eq. HOBt and 5 eq. DIC in DMF was used. Biotin labeling was performed by dissolving 3 eq. biotin in DMF for $10 \mathrm{~min}$ at $60^{\circ} \mathrm{C}$. Following, 3 eq. HOBt and 3 eq. DIC were added to the mixture, which was incubated on the resin. For 5(6)-TAMRA labeling 2 eq. 5(6)-TAMRA, 2 eq. HATU and 2 eq. DIPEA were dissolved in DMF and added to the respective resin.

Dde cleavage was obtained by addition of freshly prepared $2 \%$ $(\mathrm{v} / \mathrm{v})$ hydrazine in DMF for $10 \mathrm{~min}$ at least 10 times using an automated multiple peptide synthesis robot system.

Side chain deprotection and concurrent cleavage from the resin was accomplished by using a mixture of TFA/TA/EDT (90:7:3, $1 \mathrm{~mL})$ or TFA/TA/TK $(90: 5: 5 \mathrm{v} / \mathrm{v} / \mathrm{v})$ for Bpa containing peptides for $3 \mathrm{~h}$ at room temperature under constant shaking.

All peptides were purified by preparative reversed-phase high-performance liquid chromatography (RP-HPLC) on a PhenomenexKinetex $5 \mathrm{u}$ XB-C18 (5 $\mu \mathrm{m}, 100 \AA)$, a PhenomenexAeris $^{\mathrm{TM}}$ Peptide XB-C18 $(5 \mu \mathrm{m}, 100 \AA)$ or a Phenomenex Jupiter 10u Proteo C18 (90 ̊, $10 \mu \mathrm{m})$ column using linear gradients of $0.08 \%(\mathrm{v} / \mathrm{v})$ TFA in ACN (eluant B) in $0.1 \%(\mathrm{v} / \mathrm{v})$ TFA in $\mathrm{H}_{2} \mathrm{O}$ (eluant $\left.\mathrm{A}\right)$. Peptide purity was determined by analytical RP-HPLC using two different columns (PhenomenexAeris ${ }^{\circledR}$ Peptide 3.6u XB-C18 (3.6 $\mu \mathrm{m}, 100 \AA$, $1.55 \mathrm{~mL} / \mathrm{min}$ ), PhenomenexKinetex 5u XB-C18, $5 \mu \mathrm{m}, 100 \AA$, $1.55 \mathrm{~mL} / \mathrm{min})$. Identity was confirmed by matrix-assisted laser desorption ionization time of flight (MALDI-ToF) MS (Ultraflex III MALDI-ToF/ToF, Bruker Daltonics) and ESI-HCT MS (High-capacity ion trap ESI-MS, Bruker Daltonics). Purity of all peptides was $\geq 95 \%$.

\section{Plasmids}

Human $\mathrm{Y}_{2} \mathrm{R}$ _cysteine_deficient cDNA, containing the mutations $\mathrm{C} 58^{1.40} \mathrm{~A}, \quad \mathrm{C} 103^{2.57} \mathrm{~S}, \quad \mathrm{C} 151^{3.53} \mathrm{~S}, \quad \mathrm{C} 272^{6.39} \mathrm{~A}, \quad \mathrm{C} 316^{7.44} \mathrm{~A}$, C $342^{7.70} \mathrm{~A}$ (Witte et al., 2013), was cloned into pVITRO2-hygromcs (InvivoGen, San Diego, CA, United States), and C-terminally fused to an enhanced yellow fluorescent protein (eYFP) by an ADPPVV linker containing GCGGATCCACCGGTCGTG on the DNA level. The chimeric $G$ protein $G_{\alpha \Delta 6 q i 4 m y r}$ was cloned into pcDNA3 and was kindly provided by Kostenis (2001).

Human $\mathrm{Y}_{2}$ receptor cDNA fused to an enhanced green fluorescent protein (eGFP) by a GCGGATCCGGTGATGGTG linker (amino acid sequence ADPVMV) and human $\mathrm{Y}_{2} \mathrm{R}$ _cysteine_deficient cDNA were subcloned into the prokaryotic expression vector pET-22b $(+)$ (Merck Millipore, Darmstadt, Germany) by using NdeI and XhoI (Thermo Fisher Scientific, Braunschweig, Germany). A C-terminal deca-histidine-tag $(10 \times$ His $)$ linked by CTCGAG was added 
for purification and detection. The molecular weight of $\mathrm{Y}_{2} \mathrm{R}$ _eGFP_His 10 is $71650.6 \mathrm{Da}$ and the $\mathrm{Y}_{2} \mathrm{R}$ _cysteine_deficient has a molecular weight of 44184.4 Da.

\section{IP-One Assay}

The inositol phosphate (IP)-one assay was performed as described previously (Wanka et al., 2018). In short, confluent HEK293 cells (human embryonic kidney) in 6-well plates were co-transfected with receptor and a chimeric $G_{\alpha}$ protein $\left(\mathrm{G}_{\alpha \Delta 6 \text { 6i4myr }}\right)$. On the next day the cells were trypsinated, re-seeded in white 384-well plates (Greiner Bio-one) and maintained over night at $37^{\circ} \mathrm{C}, 5 \% \mathrm{CO}_{2}$ and $95 \%$ humidity (standard conditions). For measurement of IP production, the IP-one Gq assay kit (Cisbio Bioassay, Codolet, France) was used. The medium was removed and cells stimulated for $1.5 \mathrm{~h}$ with $15 \mu \mathrm{L}$ stimulation solution containing increasing concentrations of NPY or NPY analogs. After cell lysis with lysis buffer supplemented with antibody 1 and antibody 2 according to the manufacturer's protocol, the emission at $665 \mathrm{~nm}$ and $620 \mathrm{~nm}$ was measured in a Tecan Spark plate reader (Tecan Group AG, Männedorf, Switzerland).

Using GraphPad Prism 5.0 (GraphPad Software, San Diego, $\mathrm{CA}$, United States) the concentration response curves were normalized to the NPY $\mathrm{Y}_{2} \mathrm{R}$ curve. The $\mathrm{EC}_{50}$ and $E_{\max }$ values of concentration response-curves were determined by non-linear regression (curve fit). The experiments were conducted in at least two independent experiments.

\section{[ ${ }^{125}$ I]PYY Binding Assay}

For binding experiments, membrane preparations of transiently transfected HEK293 cells were used. For transfection, HEK293 cells were seeded into $75 \mathrm{~cm}^{2}$ culture flasks and were transiently transfected with pVitro2_Y 2 R_cysteine_deficient_eYFP $(12 \mu \mathrm{g})$ with MetafectenePRO (Biontex Laboratories $\mathrm{GmbH}$, Munich, Germany).

For membrane preparation, transiently transfected HEK293 cells were washed twice with Dulbecco's phosphate-buffered saline (DPBS, Biochrome GmbH, Berlin, Germany) and afterwards harvested with DPBS. The cells were taken up in Tris-buffer [50 mM Tris, pH 7.5, with 1\% (v/v) Pefabloc SC] and homogenized 50 times $(25 \times$ loose and $25 \times$ tight pestle) with a manual dounce homogenizer and centrifuged for $10 \mathrm{~min}$ at $2,400 \mathrm{rpm}, 4^{\circ} \mathrm{C}$. The supernatant was centrifuged again for $30 \mathrm{~min}$ at $12,000 \mathrm{rpm}$ and $4^{\circ} \mathrm{C}$ and the resulting pellet was resuspended in HEPES buffer [25 mM HEPES, $2 \mathrm{mM} \mathrm{MgCl}_{2}$ and $25 \mathrm{mM} \mathrm{CaCl}_{2}$ (Fluka, Buchs, Switzerland), $\mathrm{pH}$ 7.4], with $50 \mathrm{nM}$ Pefabloc SC. The solution was homogenized as described above and centrifuged for $30 \mathrm{~min}$ at $12,000 \mathrm{rpm}, 4^{\circ} \mathrm{C}$. The resulting membrane pellet was thoroughly resuspended in HEPES-buffer without Pefabloc SC and protein concentration was measured in triplicates by Bio-Rad Protein Assay (Bio-Rad Laboratories, Inc., Hercules, CA, United States) against a BSA fraction V (BSA, Roth, Karlsruhe, Germany) standard. Next, $50 \mathrm{nM}$ (final) Pefabloc SC was added and $100 \mu \mathrm{L}$ aliquots were stored at $-70^{\circ} \mathrm{C}$.

The competition binding assay was previously described by Kaiser et al. (2018) with minor changes. Briefly, NPY,
5(6)-TAMRA-Ahx(5-24)NPY and [ $\left.{ }^{125} \mathrm{I}\right]$-pPYY (NEX240, PerkinElmer, Boston, MA, United States) were diluted in water with $1 \%(\mathrm{w} / \mathrm{v})$ BSA. $10 \mu \mathrm{l}$ of increasing concentrations of NPY or 5(6)-TAMRA-Ahx(5-24)NPY, $10 \mu \mathrm{l}$ of [ $\left.{ }^{125} \mathrm{I}\right]$-PYY (60 pM final concentration) and $0.75 \mu \mathrm{g}$ membrane preparations in $80 \mu \mathrm{L}$, diluted in HBSS with $1 \%$ (w/v) BSA, $50 \mathrm{nM}$ Pefabloc SC to $0.75 \mu \mathrm{g}$ total protein per well were added to a 96 well plate. The incubation was performed at room temperature and with continuous shaking for $3 \mathrm{~h}$. The binding assay was terminated by filtering the samples though a glass fiber filter Printed Filtermat B (Perkin Elmer), which was presoaked with $0.1 \%$ polyethyleneimine (Fluka) in distilled water. The radioactivity was measured by using a FilterMate Harvester and Melt-on Scintillator Sheets MeltiLexA in a MicroBeta2 Plate Counter (2450 Microplate), purchased from PerkinElmer. Concentration-response curves were analyzed with GraphPad Prism 5.0, all curves were normalized to the top (100\%) and bottom $(0 \%)$ values of the NPY curve. The row means total function was used to summarize concentration-response curves of different experiments to one single concentration-response curve. $\mathrm{IC}_{50}$ and $\mathrm{pIC}_{50} \pm$ s.e.m. were examined using logistic fitting with fixed Hill Slope $\left(n_{\mathrm{H}}=1\right)$. Assays were performed in triplicates for at least two independent experiments. For $K_{\mathrm{d}}$ value determination of $\left[{ }^{125} \mathrm{I}\right] \mathrm{PYY} \quad \mathrm{Y}_{2} \mathrm{R}$ _cysteine_deficient membrane preparations ( $5 \mu \mathrm{g}$ total protein) were incubated with increasing concentrations of $\left[{ }^{125} \mathrm{I}\right] \mathrm{PYY}$ in an overall volume of $250 \mu \mathrm{L}$ for $3 \mathrm{~h}$ at room temperature under constant shaking. The assay was terminated by filtration and radioactivity measured in a liquid scintillation counter. Concentration-response curves were analyzed with GraphPad Prism 5.0 and $K_{\mathrm{d}}$ values were determined by using non-linear regression (rectangular binding hyperbola).

\section{Cell-Free Protein Expression}

Cell-free protein expression was performed by a coupled in vitro transcription/translation system as previously described (Schwarz et al., 2007) using a bacterial S30 extract from E. coli BL21 (DE3), which already contains the T7-RNA polymerase.

The S30 extract was prepared manually. In short, an overnight culture of E. coli BL21 (DE3) in $100 \mathrm{~mL}$ TB-Medium was harvested. The cells were resuspended in $2 \mathrm{~L} 2 \mathrm{x}$ YTPG medium to obtain an $\mathrm{OD}_{600}$ of $\sim 0.1$. The cells were allowed to grow at $37^{\circ} \mathrm{C}, 200 \mathrm{rpm}$ to an $\mathrm{OD}_{600}$ of 0.6 and the expression of the T7-RNA Polymerase was induced by $1 \mathrm{mM}$ IPTG (Thermo Fisher Scientific). At $\mathrm{OD}_{600}$ of 2.2-2.4 cells were harvested by centrifugation at $8,000 \mathrm{~g}, 4^{\circ} \mathrm{C}$ for $5 \mathrm{~min}$. The pellets were washed three times with $10 \mathrm{mM}$ Tris-acetate $(\mathrm{pH} 8.2$, Carl Roth $\mathrm{GmbH} \&$ Co. KG, Karlsruhe, Germany), $14 \mathrm{mM}$ $\mathrm{Mg}(\mathrm{OAc})_{2}$ (Merck Millipore), $0.6 \mathrm{mM} \mathrm{KCl}$ (Grüssing $\mathrm{GmbH}$ Analytika, Filsum, Germany) and $6 \mathrm{mM} \beta$-mercaptoethanol (Sigma-Aldrich) and centrifuged at $8,000 \mathrm{~g}, 4^{\circ} \mathrm{C}$ for $5 \mathrm{~min}$. Next, the pellet was resuspended in $1.2 \mathrm{~mL} 10 \mathrm{mM}$ Tris-acetate ( $\mathrm{pH} 8.2), 14 \mathrm{mM} \mathrm{Mg}(\mathrm{OAc})_{2}, 0.6 \mathrm{mM} \mathrm{KCl}, 1 \mathrm{mM}$ dithiothreitol (DTT, Thermo Fisher Scientific) and $1 \mathrm{mM}$ Pefabloc SC (Sigma-Aldrich). The cells were disrupted by FastPrep- $24^{\mathrm{TM}} 5 \mathrm{G}$ (MP Biomedicals, Inc.) and the lysate centrifuged at $30,000 \mathrm{~g}, 4^{\circ} \mathrm{C}$ 
for $30 \mathrm{~min}$. Centrifugation was repeated with the supernatant. The supernatant was collected, adjusted to a final concentration of $400 \mathrm{mM} \mathrm{NaCl}$ and incubated at $42^{\circ} \mathrm{C}$ for $45 \mathrm{~min}$. Subsequently the turbid extract was dialyzed against 100 times expression buffer $[10 \mathrm{mM}$ Tris-acetate ( $\mathrm{pH} 8.2), 14 \mathrm{mM} \mathrm{Mg}(\mathrm{OAc})_{2}$, $0.6 \mathrm{mM} \mathrm{KOAc}$ (Sigma-Aldrich) and $0.5 \mathrm{mM} \mathrm{DTT}$ ] for $2 \mathrm{~h}$ at $4^{\circ} \mathrm{C}$. Dialysis was repeated with fresh buffer over night. The extract was then centrifuged at $30,000 \mathrm{~g}, 4^{\circ} \mathrm{C}$ for $30 \mathrm{~min}$, the supernatant was aliquoted and stored at $-70^{\circ} \mathrm{C}$. For each new S30 extract the optimal $\mathrm{Mg}(\mathrm{OAc})_{2}$ concentration has to be adjusted. CECF protein synthesis was performed as previously described (Schwarz et al., 2007) with volumes of $75 \mu \mathrm{L}$ reaction mix (RM) and $1 \mathrm{~mL}$ feeding mix (FM) in the analytical scale and $1 \mathrm{~mL}$ $\mathrm{RM}$ and $17 \mathrm{~mL}$ FM in the preparative scale. The RM and FM consisted of the following components: $2 \%(\mathrm{w} / \mathrm{v})$ polyethylene glycol 8000 (AppliChem GmbH, Darmstadt, Germany), $1 \mathrm{mM}$ IPTG, 2 mM DTT, $150.8 \mathrm{mM}$ KOAc, $10.1 \mathrm{mM} \mathrm{Mg}(\mathrm{OAc})_{2}, 0.1 \mathrm{M}$ HEPES, 1x Halt ${ }^{\mathrm{TM}}$ Protease Inhibitor Cocktail (Thermo Fisher Scientific), $20 \mathrm{mM}$ phosphoenolpyruvate (Bachem, Bubendorf, Switzerland), $0.05 \%(\mathrm{w} / \mathrm{v})$ sodium azide, $0.1 \mathrm{mg} / \mathrm{mL}$ folinic acid, $1.2 \mu \mathrm{M}$ ATP, $0.8 \mu \mathrm{M}$ CTP, GTP and UTP (Sigma-Aldrich), $20 \mathrm{mM}$ acetyl phosphate (Sigma-Aldrich), $0.5 \mathrm{mM}$ of each amino acid (Sigma-Aldrich), supplemented with additionally $1 \mathrm{mM}$ of arginine, cysteine, tryptophane, methionine, glutamic acid and aspartic acid. The FM consisted of additional $0.5 \mathrm{mM}$ of each amino acid and 35\% expression buffer. The RM was supplemented with $0.04 \mathrm{mg} / \mathrm{mL}$ pyruvate kinase, $0.5 \mathrm{mg} / \mathrm{mL}$ tRNA (Sigma-Aldrich), $0.3 \mathrm{U} / \mu \mathrm{L}$ RNaseOUT Recombinant Ribonuclease Inhibitor (Thermo Fisher Scientific), $0.015 \mu \mathrm{g} / \mathrm{mL}$ DNA and 35\% (v/v) S30-extract.

For testing and optimization of the receptor expression, an analytical scale was used. Screening for the optimal expression temperature was accomplished by incubation at 27, 30, 33, 37, or $40^{\circ} \mathrm{C}$ for $16 \mathrm{~h}$, respectively. To obtain a soluble receptor expression $n$-dodecyl $\beta$-D-maltoside (DDM, AppliChem $\mathrm{GmbH}$ ) and Chaps (Carl Roth, Karlsruhe, Germany) were added to the RM and the feeding mix separately in final concentrations of $0.3 \%(\mathrm{w} / \mathrm{v})$ and $0.6 \%(\mathrm{w} / \mathrm{v})$. Elsewise, Brij-58 and Brij-35 (Sigma-Aldrich, Taufkirchen, Germany) were used in final concentrations of $0.01-0.5 \%(\mathrm{w} / \mathrm{v})$. Furthermore, the influence of L-glutathione oxidized (GSSG), reduced (GSH) (Carl Roth) and cholesteryl hemisuccinate (CHS) (Sigma-Aldrich) addition and the $\mathrm{pH}$ value on receptor expression was tested.

To determine the influence of additives on receptor expression Western Blots were used comparing the receptor band intensity with and without additives. The amount of solubly expressed receptor was determined by comparing the receptor band intensity in the supernatant versus the intensity in the crude reaction. To measure receptor band intensities the software Gene Tools (Syngene, Cambridge, United Kingdom) was used.

Preparative scale expression was performed as previously described (Schwarz et al., 2007; Yang et al., 2018) scaling 1 mL RM and $17 \mathrm{~mL}$ feeding mix. Soluble membrane protein expression was achieved by addition of $0.1 \%$ (w/v) Brij-35 or Brij-58, $1 \mathrm{mM}$ GSSG and $5 \mathrm{mM}$ GSH. The expression was performed for $16 \mathrm{~h}$ at $37^{\circ} \mathrm{C}$ under constant shaking.

\section{Ligand Affinity Chromatography}

After receptor expression the buffer was exchanged to a binding buffer $[0.1 \mathrm{M}$ Tris/ $\mathrm{HCl}, \mathrm{pH} 7.4,5 \%$ glycerol and $0.1 \%(w / v)$ Brij-35/-58] and samples were purified by ligand affinity chromatography using biotin-(Ahx $)_{2}-\mathrm{NPY}$ immobilized on Pierce Avidin Agarose beads (from Thermo Fisher Scientific) as previously described (Bosse et al., 2011; Yang et al., 2018). In short, the receptor was added to the immobilized biotin- $(\mathrm{Ahx})_{2}$-NPY over night at $4^{\circ} \mathrm{C}$ repetitively by using a peristaltic pump P-1 (GE Healthcare). On the next day, the column was washed five times with one bed volume of binding buffer. Elution was performed by weakening the electrostatic ligand-receptor interactions using $60 \mathrm{mM} \mathrm{CaCl} 2$ in binding buffer or by replacing the immobilized ligand from the receptor binding pocket by addition of an excess $\left(10^{-5}\right.$ and $\left.10^{-6} \mathrm{M}\right)$ of soluble ligand in the binding buffer, each two times for $30 \mathrm{~min}$ at room temperature under constant agitation. Total protein concentrations before and after ligand affinity purification were determined by Bio-Rad Protein against a BSA standard.

\section{Functionality of Cell-Free Expressed $\mathbf{Y}_{2} R$}

Functionality of cell-free expressed $\mathrm{Y}_{2} \mathrm{R}$ samples was verified by a homogenous binding assay based on fluorescence polarization as described previously (Yang et al., 2018). As fluorescent tracer, the $\mathrm{Y}_{2}$ selective NPY variant $\mathrm{Ahx}$ (5-24)-NPY (Cabrele and BeckSickinger, 2000) labeled with a 5(6)-TAMRA dye was used (5(6)-TAMRA-Ahx(5-24)NPY). In short, $\mathrm{CaCl}_{2}$ was removed from affinity purified $\mathrm{Y}_{2} \mathrm{R}$ _cysteine_deficient by dialysis and the concentration was determined by measuring $\mathrm{A}_{280}$ at a Tecan Spark plate reader (Tecan Group AG). Increasing concentrations of $\mathrm{Y}_{2} \mathrm{R}$ _cysteine_deficient in Brij-58 micelles in binding buffer were incubated with $5 \mathrm{nM}$ 5(6)-TAMRA-Ahx(5-24)NPY for 60 min under gentle agitation in opaque 96-well plates. Fluorescence was measured in a Tecan Spark plate reader using linear polarized light. The excitation wavelength was adjusted to $510 \mathrm{~nm}$ (bandwidth $10 \mathrm{~nm}$ ) and emission was measured at $590 \mathrm{~nm}$ (bandwidth $20 \mathrm{~nm}$ ) perpendicular to the excitation light plane. Experiments were conducted at least twice independently in triplicates.

\section{Photo-Crosslinking Experiment Between $Y_{2} R$ and NPY Position 27}

For photo-crosslinking $\mathrm{Y}_{2} \mathrm{R}$ _cysteine_deficient was purified by ligand affinity chromatography as previously described (Bosse et al., 2011). Elution was performed by replacing the immobilized biotin- $(\mathrm{Ahx})_{2}-\mathrm{NPY}$ in the $\mathrm{Y}_{2} \mathrm{R}$ _cysteine_deficient binding pocket with the photoactivatable NPY variant. This was performed by incubating with $10^{-5} \mathrm{M}$ Photo ${ }^{27}$-NPY in binding buffer for $30 \mathrm{~min}$ at room temperature while slightly shaking. The elution was repeated with $10^{-6} \mathrm{M}$ Photo $^{27}$-NPY. The eluted fractions were placed on ice and irradiated with UV light (UV lamp: AtlasFluotest forte, $\lambda=366 \mathrm{~nm}, 180 \mathrm{~W}$ ) for $90 \mathrm{~min} 50 \mu \mathrm{l}$ of photo-crosslinked $\mathrm{Y}_{2} \mathrm{R}$ _cysteine_deficient sample $(\sim 20 \mu \mathrm{g})$ was digested with chymotrypsin (obtained from Promega, Mannheim, Germany) according to the manufacturer's protocol. Crosslinked fragments were isolated by affinity purification 
using Monomeric Avidin Agarose beads (obtained from Thermo Fisher Scientific, Braunschweig, Germany) according to the manufacturer's protocol.

$\mathrm{Y}_{2} \mathrm{R}$ _cysteine_deficient fragments after chymotrypsin digestion were calculated by the online tool PeptideMass (Wilkins et al., 1997). The selected enzyme was "Chymotrypsin (C-term to $\mathrm{F} / \mathrm{Y} / \mathrm{W}$, not before $\mathrm{P}$ )", for the cysteine treatment the option "Iodoacetamide" was chosen and the tool was allowed for up to five missed cleavages. The Photo ${ }^{27}$-NPY fragments were calculated manually by using the program ChemDraw (PerkinElmer, Waltham, MA, United States). Possible photo-crosslinked $\mathrm{Y}_{2} \mathrm{R}$ _cysteine_deficient - Photo $^{27}$ NPY fragments were calculated by adding calculated $\mathrm{Y}_{2} \mathrm{R}$ _cysteine_deficient fragments to the Photo $^{27}$-NPY fragments containing at least the amino acids NPY (22-27). Peptide fragments of photo-crosslinked $\mathrm{Y}_{2} \mathrm{R}$ _cysteine_deficient were analyzed by MALDI-ToF MS and MS/MS using an Ultraflex III MALDI-TOF/TOF mass spectrometer in reflector mode. In addition $\mathrm{Y}_{2} \mathrm{R}$ _cysteine_deficient alone and with Photo ${ }^{27}$-NPY and an excess of NPY in a molar ration of 4:1:8 were incubated at room temperature for $30 \mathrm{~min}$ and subsequently irradiated with UV-light for $90 \mathrm{~min} 50 \mu \mathrm{L}$ of the samples were digested using chymotrypsin. The fragments were purified by monomeric Avidin Agarose beads and analyzed by MALDI-ToF MS to identify signals resulting from the receptor and unspecific photo-crosslinking. Analysis was performed manually for identification of photo-crosslinking fragments by MALDI-ToF MS. For identification of fragmentation by MS/MS, the software Biotools 2.2 (Bruker) was used, allowing crosslinking between Bpa at position 27 of NPY with one amino acid sequence of the identified receptor fragment at a time.

\section{RESULTS}

\section{Cell-Free Expression and Solubilization}

The aim of this study was to produce soluble $\mathrm{Y}_{2}$ receptor, either coupled to a C-terminal fluorescent protein or as a cysteine deficient variant, by an $E$. coli based CECF system. At first, $\mathrm{Y}_{2} \mathrm{R}$ eGFP was expressed in an analytical scale in the presence of different detergents to ensure soluble expression. Receptor production after expression was monitored by Western Blot analysis (Figure 1A and Supplementary Figure S3) of the crude RM or its supernatant after 2 min centrifugation at $13,000 \mathrm{rpm}$. The amount of solubly expressed receptor was estimated by comparison of the receptor band intensity in the crude RM with the supernatant. In the absence of detergents the receptor is expressed, but remains insoluble. For a soluble expression, detergents were added during expression. The detergents $0.3 \%(\mathrm{w} / \mathrm{v}) \mathrm{DDM}$ and $0.6 \%(\mathrm{w} / \mathrm{v})$ Chaps, which
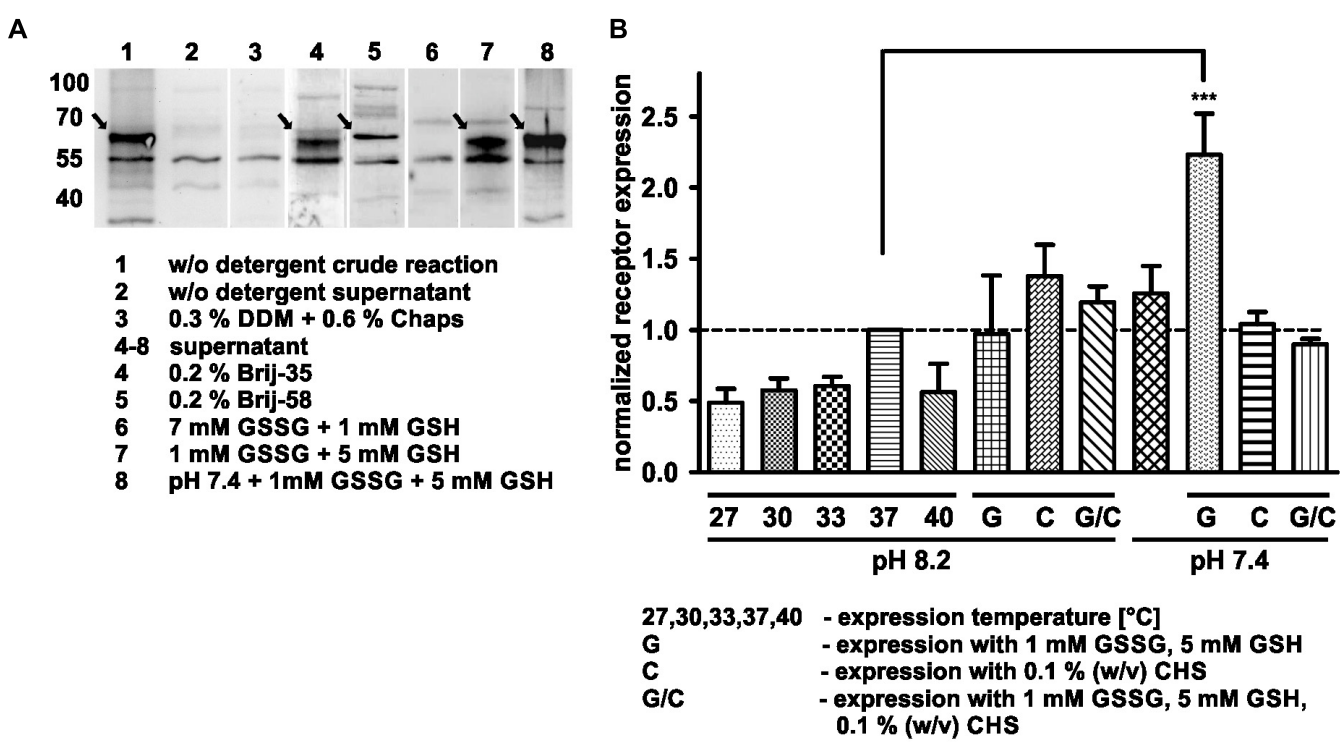

FIGURE 1 | Optimization of cell-free $Y_{2} R$ _eGFP expression. (A) Western Blot of cell-free expressed hY ${ }_{2} R \_$eGFP at different conditions (selected shown, spliced from different Western Blots). To monitor soluble receptor expression the crude reaction $(1,3)$ was centrifuged for 2 min at 13,000 rpm and the supernatant $(2$, 4-8) used for analysis. Without detergents (2), the receptor remains insoluble, while addition of DDM and Chaps (3) completely inhibits receptor expression. The addition of Brij-35 (4) or Brij-58 (5) led to high amounts of solubly expressed receptor. To promote disulfide bridge formation oxidized (GSSG) and reduced (GSH) glutathione were used. While a higher amount of GSSG inhibits soluble receptor expression (6), an increased amount of GSH promotes it (7). The effect was further increased by lowering the $\mathrm{pH}$ of expression buffer toward $\mathrm{pH} 7.4$ (8). (B) Analysis of receptor expression based on fluorescence measurements and Western Blot analysis. All samples were normalized to receptor expression at $37^{\circ} \mathrm{C}$, without additives, with expression buffer at pH 8.2. The receptor expression was tested at different temperatures $\left(27,30,33,37\right.$, and $\left.40^{\circ} \mathrm{C}\right)$ without additives and at $37^{\circ} \mathrm{C}$ with $1 \mathrm{mM} \mathrm{GSSG} / 5 \mathrm{mM} \mathrm{GSH}(\mathrm{G}), 0.1 \%$ cholesteryl hemisuccinate $(\mathrm{CHS}$, $\mathrm{C})$ or with $1 \mathrm{mM}$ GSSG, $5 \mathrm{mM}$ GSH and $0.1 \%$ cholesteryl hemisuccinate $(\mathrm{G} / \mathrm{C})$ by using an expression buffer at pH 8.2 or 7.4. The expression in the presence of $1 \mathrm{mM}$ GSSG and $5 \mathrm{mM}$ GSH at pH 7.4 leads to a significantly increased receptor expression. Arrows indicate synthesized receptors. DDM, $n$-dodecyl $\beta$-D-maltoside; Chaps, 3-[(3-cholamidopropyl)dimethylammonio]-1-propansulfonat; Brij-35, polyoxyethylene(23)laurylether; Brij-58, polyoxyethylene(20)cetylether, $n \geq 2$, *** $P<0.005$, one-way analysis of variance. 
have been used to refold the recombinantly expressed $\mathrm{Y}_{2}$ receptor (Schmidt et al., 2009), completely inhibited receptor expression in the CECF system. As an alternative the polyoxyethylene alkyl-ether Brij-35 and Brij-58, both with a critical micellar concentration below $0.1 \mathrm{mM}$, were added in final concentrations of $0.01-0.5 \%(\mathrm{w} / \mathrm{v})$. These detergents have been used for soluble expression of a number of GPCRs by cell-free systems (Klammt et al., 2005; Schwarz et al., 2007; Corin et al., 2011a; Junge et al., 2011; Isaksson et al., 2012; Orban et al., 2015). Both detergents were able to solubilize $\mathrm{Y}_{2} \mathrm{R}$ _eGFP in high amounts, with Brij-35 leading to more than $90 \%$ of soluble receptor (Table 1), while the addition of Brij-58 led to $\sim 80 \%$ of soluble $\mathrm{Y}_{2} \mathrm{R}$ _eGFP. For $\mathrm{Y}_{2} \mathrm{R}$ _cysteine_deficient the solubilization by Brij-58 was more effective, resulting in approximately $80 \%$ of soluble receptor, compared to $55 \%$ of soluble receptor when using Brij-35 (Table 1). Since high concentrations of detergents can disturb structural investigations, the amount of detergents was reduced stepwise (data not shown). For Brij-35, a minimal concentration of $0.1 \%(\mathrm{w} / \mathrm{v})$ is required for efficient receptor solubilization, while lower concentrations reduced the amount of solubly expressed $\mathrm{Y}_{2} \mathrm{R}$ _eGFP to $\sim 70 \%$. By using Brij-58, a final concentration of $0.01 \%(\mathrm{w} / \mathrm{v})$ is sufficient to solubilize $80 \%$ of expressed $\mathrm{Y}_{2} \mathrm{R} \_\mathrm{eGFP}$.

However, to ensure a stable solubilization also in a larger scale, final concentrations of $0.2 \%(\mathrm{w} / \mathrm{v})$ Brij-35 for the preparative scale expression of $\mathrm{Y}_{2} \mathrm{R} \_$eGFP or $0.1 \%(\mathrm{w} / \mathrm{v})$ Brij-58 for the expression of $\mathrm{Y}_{2} \mathrm{R}$ _cysteine_deficient were used.

\section{Optimization of Receptor Expression}

The cell-free expression system provides the advantage of easy adjustment to the requirements of the expressed protein. Thus, the $\mathrm{Y}_{2} \mathrm{R}$ _eGFP expression was optimized by changes in the expression temperature and $\mathrm{pH}$ value. The results have been normalized to the amount of receptor expressed at standard conditions $\left(37^{\circ} \mathrm{C}, \mathrm{pH} 8.2\right.$, w/o detergent) and are shown in Figure $1 \mathrm{~B}$ and Table 2. A reduction of the expression temperature to $27^{\circ} \mathrm{C}, 30^{\circ} \mathrm{C}, 33^{\circ} \mathrm{C}$ or an increase to $40^{\circ} \mathrm{C}$ reduced the amount of solubly expressed $\mathrm{Y}_{2} \mathrm{R} \_$eGFP by about $50 \%$. Adjusting the $\mathrm{pH}$ of the expression buffer toward the cytoplasmic $\mathrm{pH}$ of eukaryotic cells (Madshus, 1988) can promote the expression of eukaryotic proteins by cell-free systems. Therefore, a $\mathrm{pH} 7.4$

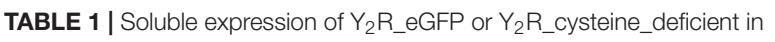
presence of different detergents.

\begin{tabular}{|c|c|c|c|c|}
\hline Detergent & $\begin{array}{l}\text { CMC } \\
{[\mathrm{mM}]}\end{array}$ & $\begin{array}{c}\text { Final } \\
\text { concentration } \\
\text { [\%] (x CMC) }\end{array}$ & $\begin{array}{c}\text { Amount of solubilize } \\
\text { receptor [\%] }\end{array}$ & \\
\hline DDM/Chaps & $0.17 / 10$ & $0.3 / 0.6(33 / 1)$ & $-*$ & \\
\hline \multirow[t]{2}{*}{ Brij-35 } & 0.09 & $0.1(9)$ & $Y_{2} R \_G F P$ & $>90$ \\
\hline & & & $Y_{2} R \_c y s t e i n e \_d e f i c i e n t$ & 55 \\
\hline \multirow[t]{2}{*}{ Brij-58 } & 0.08 & $0.1(12)$ & $Y_{2} R \_G F P$ & 80 \\
\hline & & & $\mathrm{Y}_{2} \mathrm{R}$ _cysteine_deficient & 80 \\
\hline
\end{tabular}

Non-soluble protein was removed after expression by centrifugation. Soluble fractions were determined by Western Blot Analysis with subsequent measurement of the band intensity by GeneTools (Syngene) in the soluble fraction vs. the crude reaction mix after expression. * -protein expression was inhibited.
TABLE 2 | Optimization of cell-free $Y_{2} R \_$_eGFP expression.

\begin{tabular}{|c|c|c|c|}
\hline & Expression conditions & $\begin{array}{c}\text { Receptor } \\
\text { expression (fold } \\
\text { over standard) }^{[a]}\end{array}$ & \\
\hline & \multicolumn{3}{|l|}{ Expression temperature } \\
\hline & $27 \mathrm{C}$ & 0.49 & \\
\hline & $30^{\circ} \mathrm{C}$ & 0.58 & \\
\hline & $33^{\circ} \mathrm{C}$ & 0.61 & \\
\hline & $37^{\circ} \mathrm{C}$ & 1.00 & \\
\hline & $40^{\circ} \mathrm{C}$ & 0.56 & \\
\hline $\mathrm{pH}$ value & Additives & & \\
\hline \multirow[t]{3}{*}{ pH 8.2} & GSSG, GSH & 0.97 & \\
\hline & $\mathrm{CHS}$ & 1.38 & \\
\hline & GSSG, GSH, CHS & 1.19 & \\
\hline \multirow[t]{4}{*}{$\mathrm{pH} 7.4$} & & 1.26 & \\
\hline & GSSG, GSH & 2.23 & $* * *$ \\
\hline & $\mathrm{CHS}$ & 1.04 & \\
\hline & GSSG, GSH, CHS & 0.90 & \\
\hline
\end{tabular}

Analysis of receptor expression based on fluorescence measurements and Western Blot. All samples were normalized to receptor expression at $37^{\circ} \mathrm{C}$, without additives, with expression buffer at pH 8.2. To test for their influence on receptor expression $1 \mathrm{mM}$ GSSG, $5 \mathrm{mM}$ GSH or $0.1 \%(\mathrm{~W} / \mathrm{V}) \mathrm{CHS}$ were added to the reaction mix. ${ }^{[a]}$ Standard condition $-37^{\circ} \mathrm{C}$, buffer $\mathrm{pH} 8.2,0.2 \%$ Brij-35 final, ${ }^{* * * P}<0.005$ one-way analysis of variance.

was used during $\mathrm{Y}_{2} \mathrm{R} \_\mathrm{eGFP}$ expression, increasing the amount of expressed protein by about $25 \%$.

GPCRs contain several disulfide bridges that are important for correct folding and function. To promote formation of correct disulfide bridges oxidized (GSSG) and reduced (GSH) glutathione were added during soluble expression in presence of $0.2 \%$ Brij-35. When using $7 \mathrm{mM}$ GSSG and $1 \mathrm{mM} \mathrm{GSH}$ the cell-free protein expression was strongly reduced, whereas the use of higher concentrations of GSH $(5 \mathrm{mM})$ than GSSG $(1 \mathrm{mM})$ promoted the receptor expression. Using the glutathione shuttle in combination with the reduced $\mathrm{pH}$ value significantly increased receptor expression up to twofold.

CHS is an acidic cholesterol ester, which assembles itself into bilayers and can be used in combination with detergents to enhance micelle stability and membrane protein folding (Tucker and Grisshammer, 1996). To elucidate whether CHS has a positive effect on the receptor expression and solubilization $0.1 \%$ (w/v) CHS was added to the RM in combination with $\mathrm{pH} 8.2$ or $\mathrm{pH} 7.4,0.2 \%$ Brij-35, as well as with and without addition of $1 \mathrm{mM}$ GSSG and $5 \mathrm{mM}$ GSH. However, none of these conditions led to a significant increase in receptor expression.

As for structural investigations larger amounts of receptor are needed, a preparative scale was used with the optimized conditions for soluble $\mathrm{Y}_{2} \mathrm{R}$ expression, determined in the analytical scale. An expression at pH 7.4 with $1 \mathrm{mM}$ GSSG, $5 \mathrm{mM}$ GSH and the respective detergent led to a stable and soluble receptor expression in the preparative scale and these conditions were used for further investigations. 


\section{Purification and Functionality of Cell-Free Expressed $Y_{2}$ Receptors}

For purification of the expressed receptors and to separate correctly folded from unfolded or misfolded $\mathrm{Y}_{2}$ receptors, ligand affinity chromatography was used as described by Bosse et al. (2011). For immobilization of NPY on Avidin Agarose beads NPY was biotinylated at its N terminus, which is not involved in ligand binding and signal transduction (Cabrele and Beck-Sickinger, 2000; Lindner et al., 2009) and can therefore be used for modifications. To ensure specific binding and elution an excess of soluble NPY was used to replace the biotin-NPY from the column. By comparing receptor band intensity in Western Blot analysis and silver stain (Figure 2) before and after purification by ligand affinity chromatography, an amount of about 25\% correctly folded receptor was determined. The eluted fractions contain $0.78 \mathrm{mg} \mathrm{Y} \mathrm{Y}_{2} \mathrm{R} \_$eGFP or $0.26 \mathrm{mg} \mathrm{Y}_{2} \mathrm{R} \_$cysteine_deficient, respectively, resulting from $1 \mathrm{~mL}$ of $\mathrm{RM}$. This corresponds to a yield of $4.9 \%$ for $\mathrm{Y}_{2} \mathrm{R} \_\mathrm{e}$ GFP or a yield of $2.3 \%$ for $Y_{2} R \_c y s t e i n e \_d e f i c i e n t$ (Table 3).

The interaction between $\mathrm{Y}_{2} \mathrm{R}$ and NPY $\mathrm{C}$ terminus is strongly dependent on electrostatic interaction (Merten et al., 2007), therefore, the bivalent ion $\mathrm{Ca}^{2+}$ can be used to weaken the electrostatic NPY-receptor interactions, leading to an elution of the receptor from the column. An efficient elution of the receptor can be achieved with $60 \mathrm{mM}$ calcium chloride in the binding buffer (Bosse et al., 2011). This has been used to purify $Y_{2} R \_c y s t e i n e \_d e f i c i e n t$ for the binding assay based on fluorescence polarization. Thus, affinity purified $\mathrm{Y}_{2} \mathrm{R} \_$cysteine_deficient was dialyzed to remove calcium chloride from the binding buffer and tested for its functionality by a homogenous binding assay based on fluorescence polarization. 5(6)-TAMRA labeled, $\mathrm{Y}_{2}$ selective (Kirby et al., 1993; DeCarr et al., 2007) NPY analog [5(6)-TAMRA-Ahx(5-24)NPY] was synthesized by solid phase peptide synthesis. Purity and identity were confirmed by RP-HPLC and MALDI-ToF MS (Table 4). Using an IP-one accumulation assay, 5(6)-TAMRA-Ahx(5-24)NPY was tested for its ability to activate $\mathrm{Y}_{2} \mathrm{R}$ _cysteine_deficient (Table 4 and Supplementary Figure S1). The ligand is able to fully activate the cysteine deficient $\mathrm{Y}_{2}$ receptor with a potency of $3.6 \mathrm{nM}$. To estimate binding of 5(6)-TAMRA-Ahx(524)NPY to the cell-free expressed $Y_{2} R_{-}$cysteine_deficient, a homogenous binding assay was used, which eliminates

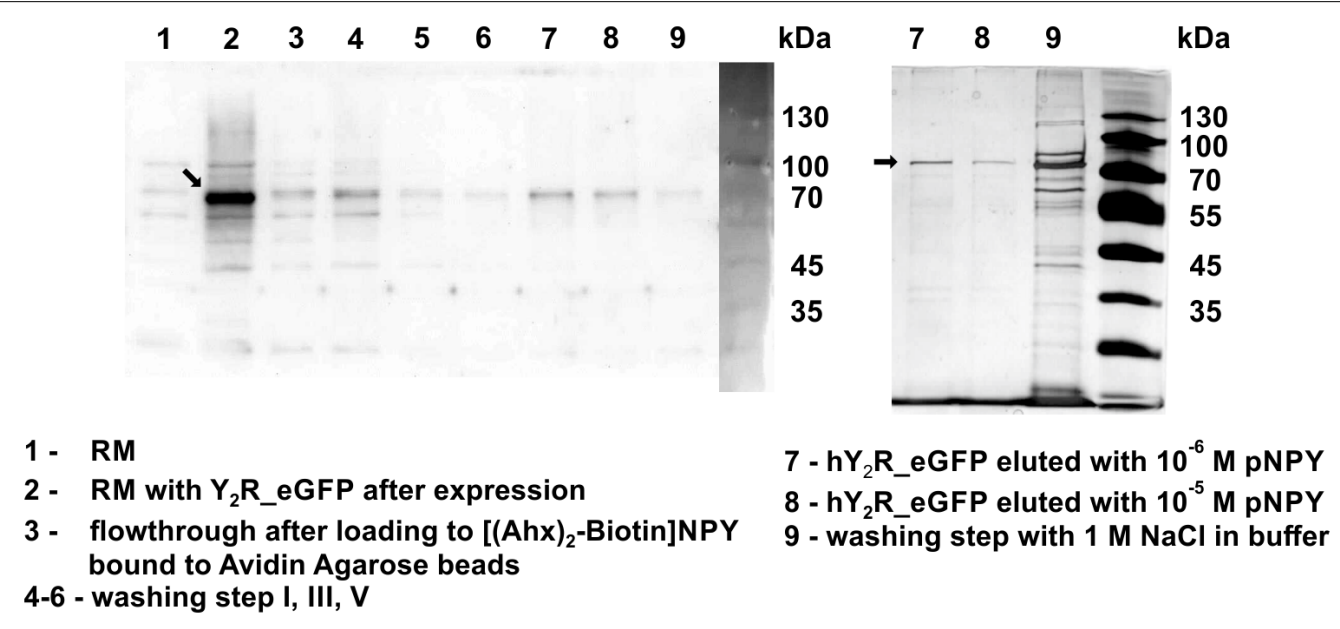

FIGURE 2 | Western Blot (left) and silver staining (right) of cell-free expressed hY ${ }_{2}$ R_eGFP before and after ligand affinity chromatography. The reaction mix (RM) was plotted before (1) and after (2) expression of $Y_{2} R_{-}$eGFP to determine a successful protein expression. Next, RM was added to biotin-(Ahx) ${ }_{2}-N P Y$ loaded columns (3) and unfolded/not correctly folded $Y_{2} R_{2}$ eGFP was washed away by multiple washing steps (4-6). Next, correctly folded receptor was eluted specifically by adding an excess of NPY, $Y_{2} R \_$_eGFP is represented by one band in lane 7, 8. After specific elution, residual $Y_{2} R_{-}$eGFP was washed from column by $1 \mathrm{M}$ NaCl in buffer (9). Arrows indicate $Y_{2} R \_$_eGFP.

TABLE 3 | Purification of cell-free expressed $Y_{2} R \_$eGFP and $Y_{2} R$ _cysteine_deficient, resulting from $1 \mathrm{~mL}$ of reaction mix.

\begin{tabular}{|c|c|c|c|c|c|}
\hline Step & & Volume $[\mathrm{mL}]$ & \multicolumn{2}{|c|}{ Total protein $^{[\mathrm{a}]}$} & Yield (\%) \\
\hline \multirow[t]{2}{*}{ Crude extract ${ }^{[b]}$} & $Y_{2} R_{\text {R_eGFP }}$ & 1 & 15.9 & & 100 \\
\hline & $Y_{2} R \_c y s t e i n e \_d e f i c i e n t$ & & 11.5 & & 100 \\
\hline Ligand affinity & $\mathrm{Y}_{2} \mathrm{R}$ _eGFP & 3 & 0.78 & 10.11 & 4.9 \\
\hline chromatography & $Y_{2} R \_c y s t e i n e \_d e f i c i e n t$ & & 0.26 & 5.16 & 2.3 \\
\hline
\end{tabular}

[a] Total protein was determined by Bio-Rad Protein Assay using BSA as standard protein. ${ }^{[b]}$ Crude extract from $1 \mathrm{~mL}$ reaction mix, which correlates to one cell-free preparative scale expression. 
TABLE 4 | Analytical characterization of NPY analogs for ligand affinity chromatography, crosslinking experiments and binding assays.

\begin{tabular}{|c|c|c|c|c|c|c|}
\hline Peptide & Chemical formula & $M_{\text {calc. }}[\mathrm{Da}]$ & $\begin{array}{l}\text { MALDI-ToF MS } \\
{[\mathrm{M}+\mathrm{H}]^{+}[\mathrm{Da}]}\end{array}$ & Purity $[\%]^{[a]}$ & $\begin{array}{c}\mathrm{EC}_{50}[\mathrm{nM}] \\
\left(\mathrm{pEC} \mathrm{C}_{50} \pm \text { s.e.m. }\right)^{[\mathrm{b}]}\end{array}$ & $\begin{array}{c}E_{\max } \pm \text { s.e.m. } \\
{[\%]^{[c]}}\end{array}$ \\
\hline NPY & $\mathrm{C}_{190} \mathrm{H}_{287} \mathrm{~N}_{55} \mathrm{O}_{57}$ & 4251.1 & 4252.0 & $>95$ & $0.1(9.79 \pm 0.15)$ & $92 \pm 4$ \\
\hline Biotin- $(\mathrm{Ahx})_{2}-\mathrm{NPY}$ & $\mathrm{C}_{212} \mathrm{H}_{323} \mathrm{~N}_{59} \mathrm{O}_{61} \mathrm{~S}$ & 4703.4 & 4704.3 & $>95$ & $1,2(8.91 \pm 0.25)$ & $98 \pm 8$ \\
\hline 5(6)-TAMRA,Ahx(5-24)NPY & $\mathrm{C} 127 \mathrm{H}_{182} \mathrm{~N}_{34} \mathrm{O}_{28}$ & 2631.4 & 2632.4 & $>95$ & $3.4(8.42 \pm 0.21)$ & $95 \pm 8$ \\
\hline$\left[\mathrm{K}^{22}\left[(\mathrm{Ahx})_{2}\right.\right.$-biotin] $\left.\mathrm{Bpa}^{27}\right] \mathrm{NPY}$ & $\mathrm{C}_{222} \mathrm{H}_{334} \mathrm{~N}_{60} \mathrm{O}_{60} \mathrm{~S}$ & 4832.5 & 4833.4 & $>95$ & $4.0(8.40 \pm 0.25)$ & $102 \pm 12$ \\
\hline
\end{tabular}

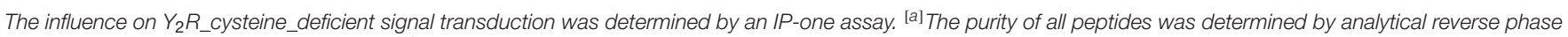

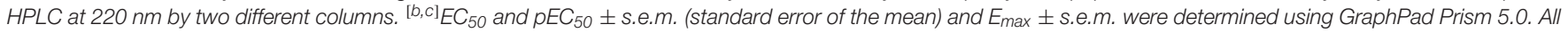
curves were normalized to the top and bottom values of the $Y_{2} R / N P Y$ curve. Non-linear regression (curve fit) was performed for normalized response in all assays $n \geq 2$.

the necessity for separation of bound from unbound ligand. 5(6)-TAMRA-Ahx(5-24)NPY was incubated with cell-free receptor in Brij-58 micelles and changes in the emission of linearly polarized fluorescence was detected (perpendicular/Splane). After ligand binding a reduction in the fluorescence in the S-plane was detected. The reduction showed a sigmoidal curve progression, displayed in Figure 3 and allowed the determination of the $\mathrm{EC}_{50}$ of $49 \mathrm{nM}\left(\mathrm{pEC}_{50}\right.$ $7.3 \pm 0.25)$ by logistic fitting, which constitutes the affinity constant $\left(K_{\mathrm{d}}\right)$. To confirm the results and compare the binding constant with a mammalian expression, additional binding experiments were performed with membrane preparations of $\mathrm{Y}_{2} \mathrm{R}$ _cysteine_deficient in HEK293 cells and $\left[{ }^{125} \mathrm{I}\right] \mathrm{PYY}$. By a displacement assay we obtained an $\mathrm{IC}_{50}$ value of $39 \mathrm{nM}$ ( $\mathrm{pIC}_{50} 7.4 \pm 0.19$ ) for 5(6)-TAMRAAhx(5-24)NPY, Figure 4, which results in an $K_{\mathrm{i}}$ value of $11.2 \mathrm{nM}$ for $5(6)$-TAMRA-Ahx $(5-24) \mathrm{NPY}\left(K_{\mathrm{d}}\right.$ value $\left[{ }^{125} \mathrm{I}\right] \mathrm{PYY}$ $24.1 \mathrm{pM} \pm 8.4$, data not shown). The $\mathrm{EC}_{50}$ value of the cell-free expressed $\mathrm{Y}_{2} \mathrm{R}$ _cysteine_deficient is only about four times higher than the $K_{\mathrm{i}}$ value determined by the radioactive binding assay. Consequently, cell-free expressed $\mathrm{Y}_{2} \mathrm{R}$ _cysteine_deficient is functional and can be used for photo-crosslinking experiments.

\section{Photo-Crosslinking Between $\mathrm{Y}_{2} \mathrm{R}$ _Cysteine_Deficient and Position 27 of NPY}

Photo-crosslinking can be used to investigate binding motifs between ligands and their respective targets. As shown by double cycle mutagenesis (Kaiser et al., 2015) $\mathrm{L}^{24}$ and $\mathrm{I}^{28}$ of the ligand bind to the ECL2 of $\mathrm{Y}_{2} \mathrm{R}$ by hydrophobic contacts, furthermore the C-terminal binding of NPY to $\mathrm{Y}_{2} \mathrm{R}$ has been intensively investigated. Based on these data a model of NPY docked into $\mathrm{Y}_{2} \mathrm{R}$ was generated by Kaiser et al. (2015). Figure 5 shows the homology model, which was adapted from this reference. For $\mathrm{Y}^{27}$ in the $\alpha$-helical part of NPY no direct interactions has been suggested by the model. Therefore, NPY analogs carrying the highly reactive Bpa (Photo ${ }^{27}$-NPY) were synthesized by solid phase peptide synthesis and tested in cell-based in vitro assays (Table 4). To ensure photo-crosslinking only with functional receptors, cell-free expressed $\mathrm{Y}_{2} \mathrm{R}$ _cysteine_deficient in Brij-58 micelles was loaded on biotin- $(\mathrm{Ahx})_{2}-\mathrm{NPY}$ columns, specifically eluted with $1 \mu \mathrm{M}$ or $10 \mu \mathrm{M}$ Photo $^{27}$-NPY, respectively,

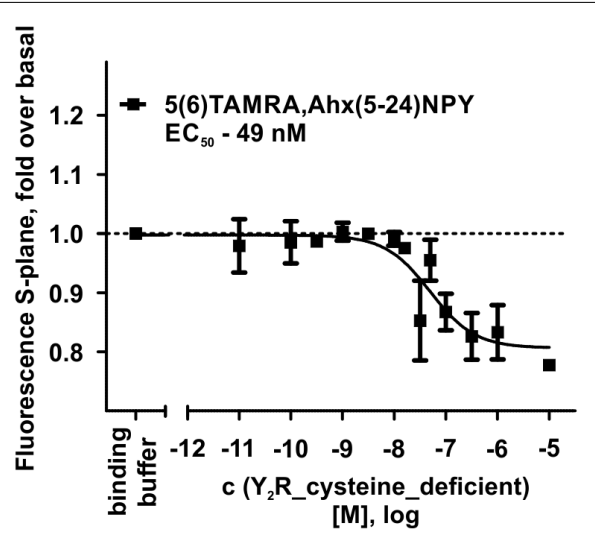

FIGURE 3 | Fluorescence polarization assay of 5 nM 5(6)-TAMRA labeled, short NPY [5(6)-TAMRA-Ahx(5-24)NPY] with increasing amounts of cell-free expressed $\mathrm{Y}_{2} \mathrm{R}_{-}$cysteine_deficient in Brij-58 micelles. Data show a reduction in fluorescence S-plane upon 5(6)-TAMRA-Ahx(5-24)NPY binding after $60 \mathrm{~min}$ incubation at room temperature. The determined $\mathrm{EC}_{50}$ value was $49 \mathrm{nM}$. $\mathrm{EC}_{50}$ and $\mathrm{pEC}_{50} \pm$ s.e.m. were determined using GraphPad Prism 5.0. All curves were baseline corrected to the S-Plane fluorescence without receptor (binding buffer) $n \geq 2$.

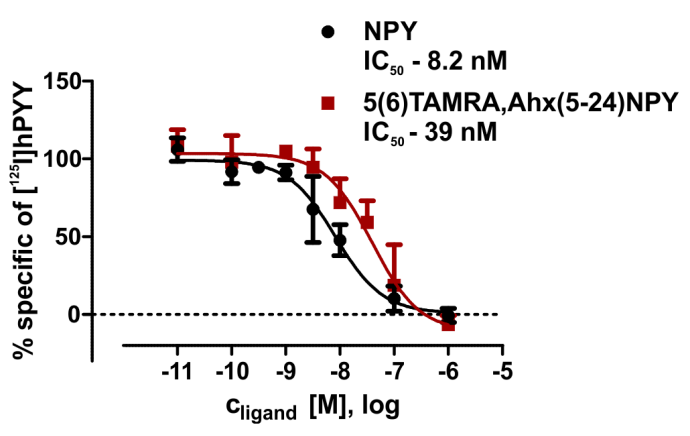

FIGURE 4 | Summary of binding assays with membrane preparations of transiently transfected HEK293 cells. $I_{50}$ values were determined by displacement assay (60 pM [ $\left.{ }^{125} \mathrm{l}\right] \mathrm{pPYY}$ ) after incubation with peptidic ligands. All curves were normalized to the associated NPY curves. Values were calculated using GraphPad Prism 5.0 non-linear regression (curve fit) $n \geq 2$.

and photo-crosslinked. The crosslinked complex was digested using chymotrypsin (Supplementary Figure S2) and resulting fragments were analyzed by MALDI-ToF MS (Figure 6 and Table 5). The signals found in the mass spectra, subtracted 

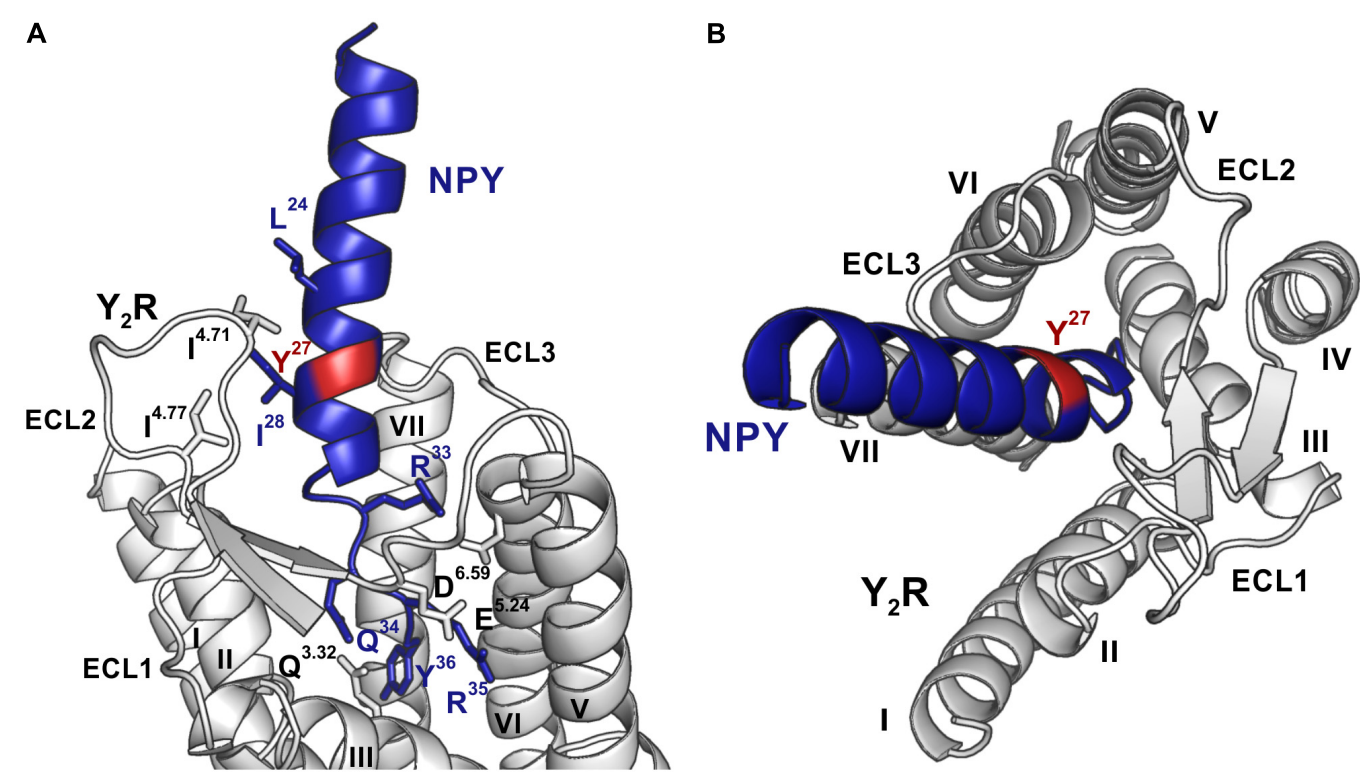

FIGURE 5 | Model of NPY bound to $Y_{2} R$, modified from Kaiser et al. (2015). Position 27, which was used for introduction of the photo-crosslinker, is highlighted in red, NPY is shown in blue and $Y_{2} R$ in gray. (A) The C-terminus of NPY unwinds upon binding to the TM helix bundle, while $\mathrm{I}^{24}$ and $\mathrm{P}^{28}$ of NPY form hydrophobic contact toward the ECL2 of $Y_{2} R$. The side-chains of residues involved in binding are shown in the respective colors and are labeled. (B) NPY has a steep binding mode, as viewed from the top, with the C-terminus of NPY binding deep inside the TM helix bundle. ECL, extracellular loop; TM, transmembrane.

by signals of the digested receptor alone and bound to native NPY, were compared to the calculated masses of the expected photo-crosslinked fragments.

These fragments were assigned to three different regions in the $\mathrm{Y}_{2} \mathrm{R}$ _cysteine_deficient, the outer parts of transmembrane helices (TM) 2 (I88-Y110), 5 (S220-Y228), 6 (A278-F287), 7 (K304-W327) and parts of TM4 and ECL2 (L167-Y189, $\mathrm{R} 187-\mathrm{F} 198)$. One mass ( $\mathrm{m} / \mathrm{z}$ 3836.9) could be assigned to either I88-Y110 or to L167-Y189 of the receptor. As no additional signals support an interaction between $\mathrm{Y}^{27}$ of the ligand and I88-Y110 of the receptor an interaction with L167-Y189 is favored. To narrow down the interaction site for position 27 we performed tandem MS/MS analysis of the signals 2665.5, 3345.0, and $3655.1(\mathrm{~m} / \mathrm{z})$. The results are shown in Figures 6, 7 and Supplementary Figure S4. We demonstrate that position 27 of NPY crosslinks to the amino acids T304, V305, and F307 in TM 7 and therefore exclude that the signal at $\mathrm{m} / \mathrm{z} 2665.5$ results from two Photo $^{27}$-NPY crosslinked to each other. By tandem MS/MS of the signal 3345.0, we identified the amino acids L284, H285, or A286 in TM 6 as being photo-crosslinked to position 27 of NPY. By fragmentation of $\mathrm{m} / \mathrm{z} 3655.1$, we can rule out $\mathrm{S} 220$ as site for photo-crosslinking, leading to the fragment L221-Y228 in TM5 as potential crosslinking site. Unfortunately, we were not able to perform MS/MS analysis of the signals, which have been assigned to the upper part of TM4 and ECL2 of the receptor. The core regions of the detected signals (G174-Y189, L222-Y228, L284-A286, and T304-F307) were labeled in the model of $\mathrm{Y}_{2} \mathrm{R}$ bound to NPY(13-36) (Figure 8).

These results indicate that there is no fixed interaction area for $\mathrm{Y}^{27}$ of the ligand, but $\mathrm{Y}^{27}$ remains flexible after binding to $\mathrm{Y}_{2} \mathrm{R}$ _cysteine_deficient and photo-crosslinking occurs with regions of the receptor, which come into proximity to the ligand by fluctuations in the ECL2 and in the TM region. Furthermore, $\mathrm{Y}^{27}$ could bind to the transmembrane helices of $\mathrm{Y}_{2} \mathrm{R}$ _cysteine_deficient subsequent to ligand binding in the suggested two-step binding mode of $\mathrm{NPY}$ to $\mathrm{Y}_{2} \mathrm{R}$.

\section{DISCUSSION}

Mass spectrometry based methods have gained more and more importance in the field of structural biology over the last years, since the instruments became more sensitive and new software for analysis is available. Crosslinking experiments are frequently used to search for unknown binding partners, to study conformational changes in proteins (Sinz, 2018) and also to map and identify binding sites in vivo (Seidel and Coin, 2018), as well as in vitro (Dehling et al., 2016; Kashiwagi et al., 2016). Thus, combined crosslinking and MS offer a complementary method to the classical structural methods like NMR spectroscopy or X-ray crystallography. In this study, we present a set-up for the in vitro production of homogenous, soluble and folded rhodopsin-like GPCRs by CF synthesis, exemplarily performed for $\mathrm{Y}_{2} \mathrm{R}$. These receptors have been used for photo-crosslinking studies in combination with MS to identify binding sites.

The challenges in GPCR expression lie within their hydrophobic and flexible nature. Different protocols have been established for the recombinant production of GPCRs from prokaryotic expression hosts (Roy et al., 2008; 


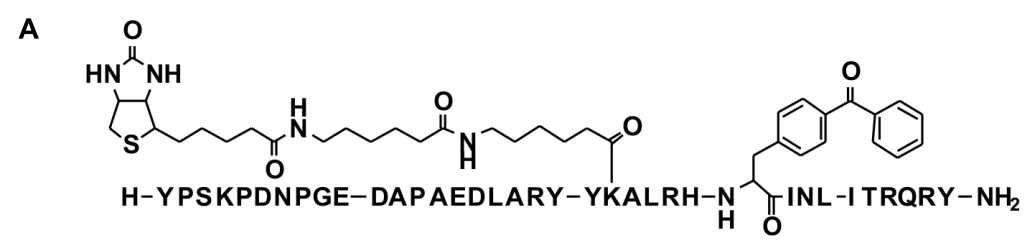

B

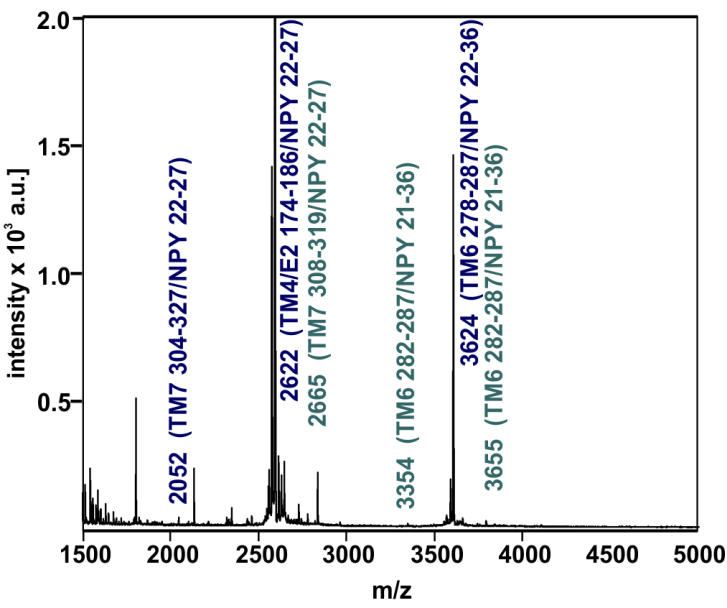

C

1 MGPIGAEADE NQTVEEMKVE QYGPQTTPRG ELVPDPEPEL IDSTKLIEVQ 51 VVLILAYASI ILLGVIGNSL VIHVVIKFKS MRTVTNFFIA NLAVADLLVN 101 2.50 TLSLPFTLTY TLMGEWKMGP VLCHLVPYAQ GLAVQVSTIT LTVIALDRHR 2.64 3.50 151 SIVYHLESKI SKRISE IIIG LAWGISALLA SPLAIFREYS LIEIIPDFEI $\underline{2} 01$ VACTEKWPGE EKSIYGTVYS LSSLLILYVV PLGIISFSYT RIWSKLKNHV $\underline{2} 51$ SPGAANDHYH QRRQKTTKML VAVVVVAAVS WLPLHAF $2 L A$ VDIDSQVLDL 301 KEYKLIF PVF HIIAMASTFA NPLLYGWMNS NYRKAFLSAF RAEQRLDAIH 351 SEVSVTFKAK KNLEVRKNSG PNDSFTEATN VLEHHHHHHH HHH

FIGURE 6 | Mass spectra of photo-crosslinked $Y_{2} R$ _cysteine_deficient with $\left[K^{22}\left[(\text { Ahx })_{2}\right.\right.$-biotin]Bpa $\left.{ }^{27}\right] N P Y$ and respective regions of NPY at $Y_{2} R$ _cysteine_deficient. (A) Structure of $\left[K^{22}\left[(A h x)_{2}\right.\right.$-biotin]Bpa $\left.{ }^{27}\right] N P Y$. (B) Exemplary MALDI-ToF mass spectrum of photo-crosslinked samples enzymatically digested with chymotrypsin. Potential $Y_{2} R$ _cysteine_deficient fragments photo-crosslinked with $\left[K^{22}\left[(A h x)_{2}\right.\right.$-biotin]Bpa $\left.{ }^{27}\right] N P Y$ are labeled in blue, fragments which were analyzed by tandem MS

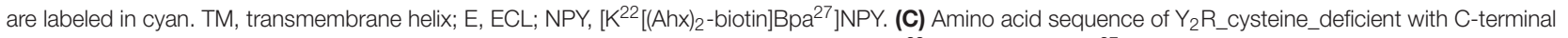

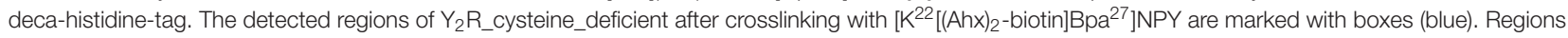
analyzed by MS/MS are emphasized by cyan boxes. The different sizes of the boxes represent different detected fragments. All experiments were repeated at least two times, independently.

TABLE 5 | Signals of photo-crosslinked $Y_{2} R$ _cysteine_deficient with $\left[K^{22}\left[(A h x)_{2}\right.\right.$-biotin]Bpa $\left.{ }^{27}\right]$ NPY identified by MALDI-ToF mass spectrometry that correlate with the calculated masses of photo-crosslinked fragments of $Y_{2} R_{-}$cysteine_deficient with $\left[K^{22}\left[(A h x)_{2}\right.\right.$-biotin]Bpa $\left.{ }^{27}\right] N P Y$ and $\left[K^{22}\left[(A h x)_{2}-\right.\right.$ biotin]Bpa $\left.{ }^{27}\right] N P Y$ with itself and are found in at least two independent experiments.

\begin{tabular}{|c|c|c|c|c|c|c|c|}
\hline $\begin{array}{l}\text { MALDI-ToF } \\
\text { MS[m/z] }\end{array}$ & $\begin{array}{l}\text { Number in } \mathbf{Y}_{2} \mathbf{R}_{-} \\
\text {cysteine_deficient }\end{array}$ & $\begin{array}{l}\text { Position in } Y_{2} R_{-} \\
\text {cysteine_deficient }\end{array}$ & Position NPY & $M_{\text {calc. }}[\mathrm{Da}]^{[b]}$ & $\underset{[\mathrm{Da}]^{[\mathrm{c}]}}{\left[M_{\text {calc }}+\mathrm{H}\right]^{+}}$ & $\underset{[\mathrm{Da}]^{[\mathrm{d}]}}{\left[\mathrm{M}_{\mathrm{calc}}+\mathrm{Na}\right]^{+}}$ & $\begin{array}{c}{\left[M_{\text {calc }}+\mathbf{K}\right]^{+}} \\
{[\mathrm{Da}]^{[\mathrm{e}]}}\end{array}$ \\
\hline 2051.9 & 304-327 & $7.32-7.55$ & $22-27$ & 4080.2 & 4081.2 & 4103.2 & 4119.2 \\
\hline 2621.6 & $174-186$ & $4.51-4.63$ & $22-27$ & 2599.5 & 2600.5 & 2622.5 & 2638.4 \\
\hline \multirow[t]{3}{*}{2665.5} & 308-319 & $7.36-7.48$ & $22-27$ & 2664.4 & 2665.4 & 2687.4 & 2703.4 \\
\hline & & & $22-36+21-21$ & 2664.5 & 2665.5 & 2687.5 & 2703.5 \\
\hline & & & $21-27+28-36$ & 2664.5 & 2665.5 & 2687.5 & 2703.4 \\
\hline 2845.2 & $187-198$ & $4.64-4.75$ & $22-27$ & 2821.5 & 2822.5 & 2844.5 & 2860.5 \\
\hline 3345.0 & $282-287$ & $6.49-6.54$ & $21-36$ & 3343.9 & 3344.9 & 3366.9 & 3382.8 \\
\hline 3624.2 & 278-287 & $6.45-6.54$ & $22-36$ & 3623.0 & 3624.0 & 3646.0 & 3662.0 \\
\hline 3655.1 & $220-228$ & $5.39-5.47$ & $21-36$ & 3654.1 & 3655.1 & 3677.1 & 3693.0 \\
\hline \multirow[t]{2}{*}{3836.9} & $88-110$ & $2.43-2.64$ & $22-27$ & 3836.1 & 3837.1 & 3859.1 & 3875.1 \\
\hline & $167-189$ & $4.44-4.66$ & $22-27$ & 3814.2 & 3815.2 & 3837.2 & 3853.1 \\
\hline 4102.6 & $304-327$ & $7.32-7.55$ & $22-27$ & 4080.2 & 4081.2 & 4103.2 & 4119.2 \\
\hline 4524.8 & $167-186$ & $5.35-5.62$ & $22-36$ & 4522.6 & 4523.7 & 4545.6 & 4561.6 \\
\hline
\end{tabular}

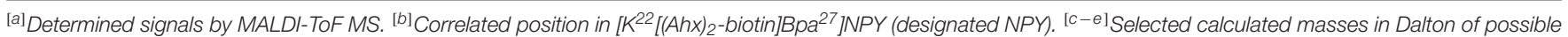

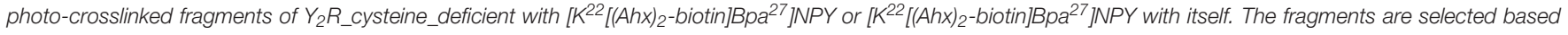
on the correlation with the detected signals. For clarity, further calculated masses of possible photo-crosslinked fragments are not shown.

Schmidt et al., 2009; Tapaneeyakorn et al., 2010; Shimamura et al., 2011) and these often contain several resolubilization, refolding, purification and stabilization steps. Therefore, this procedure is time consuming and the initial optimization process to produce large amounts of correctly folded GPCRs is labor intensive. 


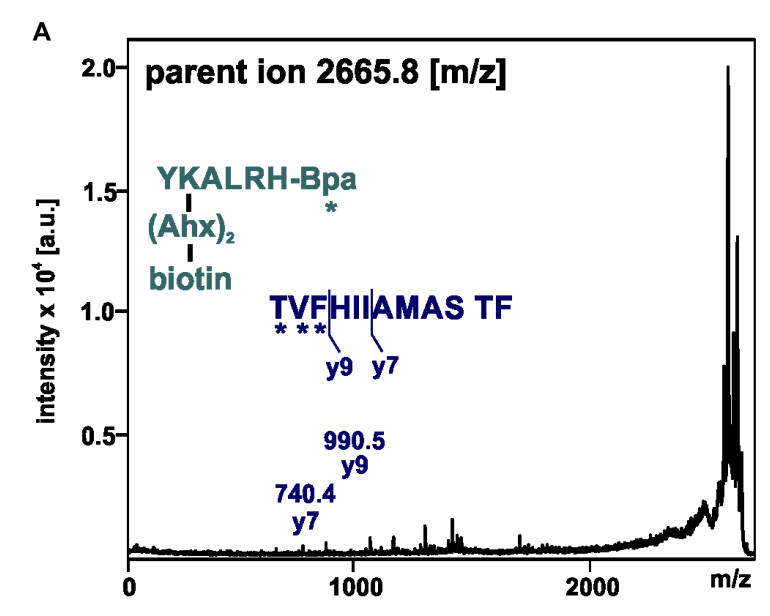

B
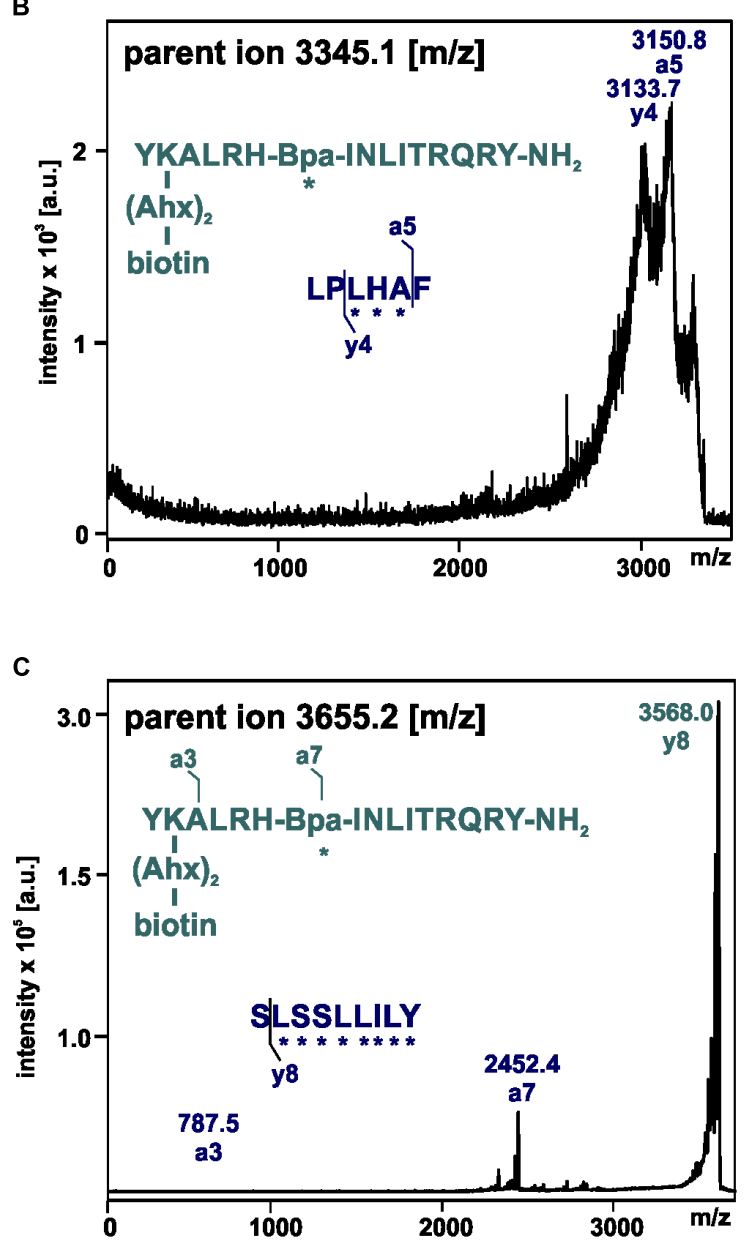

FIGURE 7 | Mass spectra of MS/MS analysis of the signals m/z 2665.8 (A), 3345.1 (B), and 3655.2 (C) resulting from photo-crosslinked $\mathrm{Y}_{2} \mathrm{R}$ _cysteine_deficient with $\left[\mathrm{K}^{22}\left[(\mathrm{~A} h \mathrm{x})_{2}\right.\right.$-biotin]Bpa $\left.{ }^{27}\right] N P Y$. Amino acid

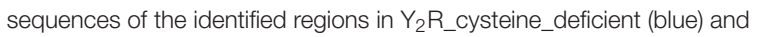
$\left[\mathrm{K}^{22}\left[(\mathrm{Ahx})_{2}\right.\right.$-biotin]Bpa $\left.{ }^{27}\right] \mathrm{NPY}$ (cyan) are depicted with the fragmentation sites resulting from collision induced dissociation (y) or electron detachment dissociation (a). Mass spectra were analyzed using Biotools 2.2. * potential site of photo-crosslinking.

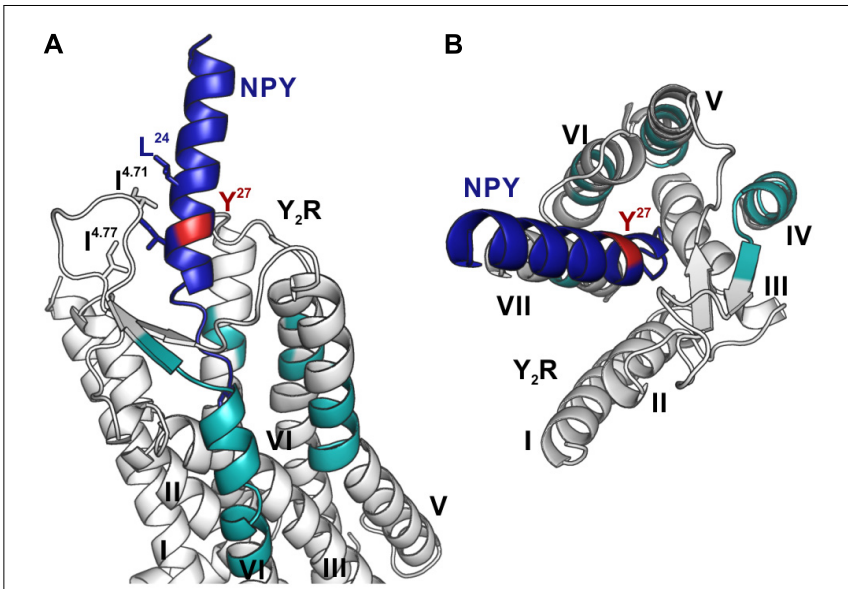

FIGURE 8 | Model of NPY bound to $Y_{2} R$. Fragments, which were identified by photo-crosslinking studies in combination with MALDI-ToF MS and tandem MS/MS, between position 27 (red) of NPY (blue) and $Y_{2} R \_c y s t e i n e \_d e f i c i e n t$ (gray) are labeled in cyan. The model is based on the model by Kaiser et al. (2015). (A) Position 27 of NPY binds toward the top of TM 5, 6, 7 as well as to the top of TM 4 and ECL2, reflecting the flexibility of this position, which has no fixed interaction partner. (B) Top view of NPY binding to $Y_{2} R$.

An alternative approach for the fast production of GPCRs are CF expression systems, which are frequently used for the expression of biomolecules otherwise hard to express, like toxic proteins (Orth et al., 2011; Villate et al., 2012), vaccines and small bioactive peptides (Lee et al., 2010; Tsuboi et al., 2010) and membrane proteins.

The expression of the $\mathrm{Y}_{2} \mathrm{R}$ by the CECF system was optimized with respect to expression temperature, buffer $\mathrm{pH}$, detergents and additives as shown in Figure $\mathbf{1}$ and Tables 1, 2. This optimization was performed in an analytical scale. For co-translational solubilization of GPCRs expressed by an E. coli based CF system polyoxyethylene ethers are widely used, which are rather mild detergents. With these derivatives different GPCRs were successfully solubilized, including the human $\beta 2$ adrenergic receptor, the human muscarinic acetylcholine receptor $\mathrm{M} 2$, the rat neurotensin receptor (Ishihara et al., 2005), the human endothelin $\mathrm{B}$ receptor and neuropeptide $\mathrm{Y}_{4}$ receptor, the human (Klammt et al., 2007), and rat vasopressin type 2 receptor (Klammt et al., 2005), the human trace amine-associated receptor 5 (Wang et al., 2013), the human endothelin A receptor (Junge et al., 2011), as well as different olfactory receptors (Corin et al., 2011b). We demonstrate that the use of either $0.2 \%(\mathrm{w} / \mathrm{v})$ Brij-35 for $\mathrm{Y}_{2} \mathrm{R}$ _eGFP, or $0.1 \%(\mathrm{w} / \mathrm{v})$ Brij-58 for the cysteine deficient $\mathrm{Y}_{2} \mathrm{R}$, yields solubilization of about $80 \%$ receptor during expression. Protein expression is strongly dependent on the expression temperature, which has to be optimized for different proteins. We tested five different expression temperatures, as shown in Table 2. Compared to the initial expression temperature of $37^{\circ} \mathrm{C}$, receptor expression was strongly reduced when lowering or increasing the temperature. As a stable redox potential is crucial for prolonged protein expression, a glutathione shuttle was added during expression, which has been shown to be beneficial for the expression of disulfide-containing proteins 
(Bundy and Swartz, 2011; Michel and Wüthrich, 2012). We further demonstrate that the addition of $1 \mathrm{mM}$ GSSG and $5 \mathrm{mM}$ GSH at a buffer $\mathrm{pH}$ of 7.4 leads to a twofold increased receptor expression compared to standard conditions. These optimized expression conditions were applied to the preparative scale expression for functional and structural investigations.

Ligand binding abilities of the expressed receptors have been monitored by ligand affinity chromatography, which was also used for purification and separation of correctly folded and unfolded or misfolded receptors. The elution was achieved by addition of an excess of soluble NPY, whereby the receptors are eluted specifically by competition of the immobilized ligand. Based on ligand affinity chromatography an amount of about $25 \%$ of correctly folded receptors was estimated (Figure 2), which corresponds to $0.78 \mathrm{mg} \mathrm{Y}_{2} \mathrm{R} \_\mathrm{eGFP}$ and $0.26 \mathrm{mg} \mathrm{Y} \mathrm{Y}_{2} \mathrm{R}$ _cysteine_deficient per $1 \mathrm{~mL}$ of RM. This is comparable to the amount of folded receptors achieved by recombinant expression with subsequent in vitro folding (Bosse et al., 2011). With costs for the production of $1 \mathrm{mg}$ correctly folded receptor varying from $50 €$ for $Y_{2} R \_$eGFP to $190 €$ for $\mathrm{Y}_{2} \mathrm{R}$ _cysteine_deficient this method is more expensive than the expression in E. coli. Nevertheless, cell-free expression techniques are very effective when considering labeling with, for example, isotopic labeled amino acids, which can be added in quite low amounts. Per preparative scale expression (1 mL RM) $34 \mathrm{nmol}$ for $\mathrm{R}, \mathrm{C}, \mathrm{W}, \mathrm{M}, \mathrm{D}$, and $\mathrm{E}$ or $18 \mathrm{nmol}$ of the other amino acids are needed. For isotopic labeling a further optimization, especially for $\mathrm{Y}_{2} \mathrm{R} \_$cysteine_deficient, should be considered to reduce the costs for the production of $1 \mathrm{mg}$ folded receptor.

To confirm the activity of affinity purified $\mathrm{Y}_{2} \mathrm{R} \_$cysteine_deficient, we aimed to perform binding assays. One problem to consider, when dealing with proteins solubilized in small detergent micelles, is the application of heterologous assays, since the micelles are too small for most filtration techniques. An alternative approach is the immobilization of the protein on functionalized beads, which, however, leads to high unspecific binding, especially when dealing with sticky peptidic ligands like NPY. Therefore, a homogenous binding assay based on fluorescence polarization was used, as already performed for the CF expressed $Y_{1} R$ (Yang et al., 2018). For the $\mathrm{Y}_{2} \mathrm{R}$ _cysteine_deficient we used a 5(6)-TAMRA-labeled, $\mathrm{Y}_{2} \mathrm{R}$ selective NPY analog. By receptor binding the ligand is restricted in its movement, which can be observed by changes in the fluorescence S-plane. Using different concentrations of $\mathrm{Y}_{2} \mathrm{R} \_$cysteine_deficient in Brij-58 micelles, an $\mathrm{EC}_{50}$ value of $49 \mathrm{nM}$ has been determined (Figure 3). By radioactive binding experiments the $K_{\mathrm{i}}$ value of 5(6)-TAMRA-Ahx(5-24)NPY was determined with $11.2 \mathrm{nM}$ (Figure 4). The $\mathrm{EC}_{50}$ value determined by fluorescence polarization assay (which equals the $K_{\mathrm{d}}$ value of this experiment) is about four times higher than the determined $K_{\mathrm{i}}$ value. This very mild reduction of affinity likely originates from the artificial surrounding the $\mathrm{Y}_{2} \mathrm{R} \_$cysteine_deficient is folded into. Nonetheless, we were able to prove that the $\mathrm{CF}$ expressed, cysteine deficient $\mathrm{Y}_{2} \mathrm{R}$ in Brij-58 micelles is able to bind the ligand and that the binding is saturable. Therefore, we assume a correct folding of the receptor.
These findings demonstrate that the soluble CF expression is an efficient alternative to existing expression and refolding protocols, since the screening for suitable detergents can be performed in parallel in small scales. After identification of a suitable detergent the expression and solubilization can be achieved within 1 day. In contrast, expression of GPCRs in E. coli with subsequent, isolation and refolding protocols include several purification and solubilization steps. Most strategies use an initial solubilization in strong, denaturating detergents like sodium dodecyl sulfate, following an exchange to mild detergents or amphipols (Schmidt et al., 2009, 2017; Banères et al., 2011). For CF based methods optimization can be done straight forward for protein stabilizing agents, as well as for redox conditions as reviewed (Bernhard and Tozawa, 2013; Hoffmann et al., 2018).

We performed photo-crosslinking studies between the affinity purified $\mathrm{Y}_{2} \mathrm{R} \_$cysteine_deficient and Photo $^{27}$-NPY. The benzophenone moiety used in Photo $^{27}$-NPY can be activated at biocompatible wavelengths of $360 \mathrm{~nm}$, which lowers the risk of damaging biomolecules (Dormán and Prestwich, 1994; Weber and Beck-Sickinger, 1997; Smith and Collins, 2015). Benzophenone was incorporated into the peptidic ligand NPY at position 27 as Bpa building block during the SPPS. This replacement is tolerated by the $\mathrm{Y}_{2}$ receptor, leading to only a minor loss of affinity (Beck-Sickinger et al., 1994; Cabrele and Beck-Sickinger, 2000). In addition to the crosslinking moiety, a biotin label was introduced at position 22 of NPY by a lysine side chain and a spacer made up from two Ahx residues. This allows separation of photo-crosslinked $\mathrm{Y}_{2} \mathrm{R} \_$cysteine_deficient fragments from non-crosslinked parts of the receptor by affinity purification exploiting the high affinity binding of biotin to avidin and streptavidin (Wilchek and Bayer, 1988; Dundas et al., 2013). This reduces the number of signals detected in the mass spectra. Furthermore, Brij-58 micelles can be washed from the photo-crosslinked fragments, since it disturbs the measurement by MS, leading to high, repetitive signals in the range of 500-1,500 Da.

To ensure specific photo-crosslinking, the $\mathrm{Y}_{2} \mathrm{R} \_$cysteine_deficient was loaded on immobilized biotin-(Ahx $)_{2}$-NPY and unbound or weakly bound receptor was washed from the column. The receptor was eluted by displacing the immobilized biotin-(Ahx) $)_{2}$-NPY with Photo $^{27}$-NPY. Subsequently the samples were photo-crosslinked, digested and affinity purified. Identification of residual $Y_{2} R \_c y s t e i n e \_d e f i c i e n t$ fragments after affinity purification was achieved by digesting the receptor without ligand with subsequent affinity purification and MS measurement. To exclude false identification of interaction sites between $\mathrm{Y}_{2} \mathrm{R}$ _cysteine_deficient and Photo $^{27}$-NPY by unspecific photo-crosslinking, UV excitation was performed in presence of an excess of NPY, which should block the specific binding site in the receptor. Remaining Photo ${ }^{27}$-NPY can only unspecifically photo-crosslink with the receptor under those conditions. These signals were identified by MS and have been excluded from the analysis of the binding site.

Based on the signals in the mass spectra after photo-crosslinking, four regions of $Y_{2} R$ have been identified 
for making variable contacts with position 27 in NPY (Figure 6 and Table 5). In addition, we performed MS/MS tandem analysis of three of the identified regions to narrow the number of potential interaction points (Figure 7 and Supplementary Figure S4). This leads to the following sites for photo-crosslinking of position 27 of NPY: the outer parts of TM5 (L221-Y228), 6 (L284-F287), 7 (T304-F307) and parts of TM4 and ECL2 (core region G174-Y189). These findings are in agreement with the suggested binding mode of NPY on $\mathrm{Y}_{2} \mathrm{R}$, which has been widely investigated by NMR spectroscopy, mutagenesis studies, as well as molecular modeling, leading to a model of $\mathrm{Y}_{2} \mathrm{R}$ bound to NPY(1336) (Figure 5) (Kaiser et al., 2015). On $Y_{2} R, N P Y$ adopts a steep binding mode, with the last $\mathrm{C}$-terminal amino acids binding deep inside the TM helix bundle. This C-terminal part of NPY [NPY(25-36)] is crucial for the binding to $\mathrm{Y}_{2} \mathrm{R}$ and unwinds upon binding to the receptor. The $\mathrm{N}$-terminal part of NPY can be truncated without affecting the affinity, which is different from the other receptors of the NPY family (Kirby et al., 1993; Beck-Sickinger and Jung, 1995; Cabrele and Beck-Sickinger, 2000; Cabrele et al., 2001; DeCarr et al., 2007). Moreover, the $\mathrm{Y}_{2} \mathrm{R}$ also tolerates an exchange of a part of the amphipathic $\alpha$-helix $([\operatorname{Ahx}(5-24)] N P Y)$ (Kirby et al., 1993). Two positions in the amphipathic $\alpha$-helix of NPY (namely $\mathrm{I}^{24}$ and $\mathrm{I}^{28}$ ) make hydrophobic contacts to the flexible ECL2 of $\mathrm{Y}_{2} \mathrm{R}$ (Kaiser et al., 2015). These contacts seem to guide the unwinding of the last five $\mathrm{C}$-terminal residues to contact the deep binding pocket.

$\mathrm{Y}^{27}$ of NPY has no fixed interaction region, but is important for the structural integrity of NPY, since bulky amino acids are well tolerated at this position (Beck-Sickinger et al., 1994; Cabrele and Beck-Sickinger, 2000). It has been stated, that the position of NPY in the binding pocket of $\mathrm{Y}_{2} \mathrm{R}$ is not static (Kaiser et al., 2015) and may follow the movement of the ECL2, which is highly flexible. Based on our findings we propose, that the flexibility of NPY brings position 27 in proximity to the TM's $4-7$, allowing crosslinking to occur on variable parts of the receptor.

It is important to note, that by crosslinking approaches always an ensemble of conformations is identified (Sinz, 2018), as also seen during photo-crosslinking between $\mathrm{Y}_{1} \mathrm{R}$ and $\left[\mathrm{Bpa}^{1}, \mathrm{~K}^{4}\left[(\mathrm{Ahx})_{2}\right.\right.$-biotin] $] \mathrm{NPY}$ (Yang et al., 2018). In this study fragments found in the mass spectra, have been assigned to two different regions in $\mathrm{Y}_{1} \mathrm{R}$ : The ECL2 - which is the binding partner for the NPY $\mathrm{N}$ terminus, as suggested by modeling and mutagenesis studies, and the $\mathrm{N}$ terminus of $\mathrm{Y}_{1} \mathrm{R}$, which is not necessary for receptor activation but significantly reduces NPY binding affinity when being removed (Lindner et al., 2009). For NPY and PYY a two-step binding mechanism has been proposed. In the first step monomeric NPY associates with the micellar/lipid surrounding, which forms hydrophobic contacts with the $\alpha$-helix (Bader et al., 2001; Lerch et al., 2002; Thomas et al., 2005, 2009). The second step involves the entrance of NPY through the helices into the binding pocket (Bettio et al., 2002; Lerch et al., 2004; Thomas et al., 2005). The $\mathrm{N}$ terminus of $\mathrm{Y}_{1} \mathrm{R}$ seems to be involved in this binding mechanism of NPY and important for guidance of the ligand into the binding pocket. This entrance is also "captured" by the photo-crosslinking approach. The regions identified by photo-crosslinking between Photo ${ }^{27}$-NPY and $\mathrm{Y}_{2} \mathrm{R}$ also reflect different conformations of NPY during binding, as well as in the final binding mode. $\mathrm{Y}^{27}$, without fixed interaction partner, is able to crosslink with all regions, which come in proximity during the binding mechanism. This binding involves an additional step, the unwinding of the C-terminal NPY residues and binding in the deep binding pocket. During this mechanism, $\mathrm{Y}^{27}$ is also repositioned relative to $\mathrm{Y}_{2} \mathrm{R}$, which is reflected by the different regions identified by MS after photo-crosslinking.

Overall our findings are in agreement with the proposed binding mode of $\mathrm{Y}_{2} \mathrm{R}$ to $\mathrm{NPY}(13-36)$ and demonstrate the robustness of the combined approach of CF synthesis and photo-crosslinking with subsequent MS. $\mathrm{Y}^{27}$ has no fixed interaction partner when bound to $\mathrm{Y}_{2} \mathrm{R}$, but is important for the structural integrity of the peptide. Thus, our approach confirmed the proposed binding mode and no single interaction site was found, but an ensemble of different sites, which come into proximity during binding and activation of the receptor. This shows that our approach leads to no false-positive interaction sites, but, when carried out precisely, also shows the flexibility of some regions.

In this study, cell-free expressed $\mathrm{Y}_{2} \mathrm{R}$ was used for interaction studies by photo-crosslinking in combination with MS. We were able to successfully produce soluble, folded and functional $\mathrm{Y}_{2} \mathrm{R}$ by an E. coli based CECF system. The expression was optimized toward expression amount and receptor solubilization. By affinity purification $0.78 \mathrm{mg}$ of pure, folded $\mathrm{Y}_{2} \mathrm{R} \_$eGFP or $0.26 \mathrm{mg} \mathrm{Y}_{2} \mathrm{R}$ _cysteine_deficient were isolated. By homogenous binding assay, functionality of $\mathrm{Y}_{2} \mathrm{R}$ _cysteine_deficient was confirmed and photo-crosslinking studies between Photo ${ }^{27}$-NPY and $\mathrm{CF}$ expressed receptor were performed. We demonstrate that $\mathrm{Y}^{27} \mathrm{NPY}$ remains flexible during binding to $\mathrm{Y}_{2} \mathrm{R}$, since photo-crosslinking has been observed with different regions in TM5-TM7, as well as TM4 and ECL2. This is in agreement with the proposed binding model of NPY(13-36) with $\mathrm{Y}_{2} \mathrm{R}$.

The cell-free expression is a powerful tool, enabling a fast and straight forward labeling of the expressed proteins site-specific with unnatural or isotopically labeled amino acids (Staunton et al., 2006; Bundy and Swartz, 2010; Su et al., 2011; Hong et al., 2014). Incorporation of photoactive amino acids, like photo-leucine or photo-methionine (Suchanek et al., 2005) by the E. coli translation machinery or the site-specific incorporation of unnatural photo-activatable amino acids like Bpa can be easily addressed. The cysteine deficient $\mathrm{Y}_{2}$ receptor variant, expressed by cell-free systems, offers the possibility of labeling by selective re-introduction of cysteines. This enables to perform labeling for photo-crosslinking experiments also from the receptor site by cell-free expression, giving further insights into interaction sites. Furthermore, site-specific introduction of amino acids into the protein allows for the introduction of other functionalities for structural investigations. This includes the possibility to introduce isotopically labeled amino acids for NMR spectroscopy or spin label for electron paramagnetic resonance spectroscopy in GPCRs in a fast and efficient way by cell-free expression. 


\section{DATA AVAILABILITY}

All datasets generated for this study are included in the manuscript and/or the Supplementary Files.

\section{AUTHOR CONTRIBUTIONS}

LK and AK performed the experiments. LK wrote the manuscript. JS and AB-S supervised the experiments and corrected the manuscript. AB-S conceived the experiments. All authors analyzed the data.

\section{FUNDING}

The financial contribution of the DFG (SFB 1052/A3), the German Federal Ministry of Education and Research

\section{REFERENCES}

Bader, R., Bettio, A., Beck-Sickinger, A. G., and Zerbe, O. (2001). Structure and dynamics of micelle-bound neuropeptide Y: comparison with unligated NPY and implications for receptor selection. J. Mol. Biol. 305, 307-329. doi: 10.1006/ jmbi.2000.4264

Banères, J. L., Popot, J. L., and Mouillac, B. (2011). New advances in production and functional folding of G-protein-coupled receptors. Trends Biotechnol. 29, 314-322. doi: 10.1016/j.tibtech.2011.03.002

Beck-Sickinger, A. G., and Jung, G. (1995). Structure-activity relationships of neuropeptide $\mathrm{Y}$ analogues with respect to $\mathrm{Y} 1$ and $\mathrm{Y} 2$ receptors. Biopolymers 37, 123-142. doi: 10.1002/bip.360370207

Beck-Sickinger, A. G., Wieland, H. A., Wittneben, H., Willim, K. D., Rudolf, K., and Jung, G. (1994). Complete L-alanine scan of neuropeptide Y reveals ligands binding to Y1 and Y2 receptors with distinguished conformations. Eur. J. Biochem. 225, 947-958. doi: 10.1111/j.1432-1033.1994.0947b.x

Bernhard, F., and Tozawa, Y. (2013). Cell-free expression-making a mark. Curr. Opin. Struct. Biol. 23, 374-380. doi: 10.1016/j.sbi.2013.03.012

Bettio, A., Dinger, M. C., and Beck-Sickinger, A. G. (2002). The neuropeptide Y monomer in solution is not folded in the pancreatic-polypeptide fold. Protein Sci. 11, 1834-1844. doi: 10.1110/ps.0204902

Bosse, M., Thomas, L., Hassert, R., Beck-Sickinger, A. G., Huster, D., and Schmidt, P. (2011). Assessment of a fully active class A G protein-coupled receptor isolated from in vitro folding. Biochemistry 50, 9817-9825. doi: 10 . 1021/bi201320e

Brothers, S. P., and Wahlestedt, C. (2010). Therapeutic potential of neuropeptide Y (NPY) receptor ligands. EMBO Mol. Med. 2, 429-439. doi: 10.1002/emmm. 201000100

Bundy, B. C., and Swartz, J. R. (2010). Site-specific incorporation of p-propargyloxyphenylalanine in a cell-free environment for direct protein-protein click conjugation. Bioconjugate Chem. 21, 255-263. doi: $10.1021 /$ bc 9002844

Bundy, B. C., and Swartz, J. R. (2011). Efficient disulfide bond formation in virus-like particles. J. Biotechnol. 154, 230-239. doi: 10.1016/j.jbiotec.2011. 04.011

Cabrele, C., and Beck-Sickinger, A. G. (2000). Molecular characterization of the ligand-receptor interaction of the neuropeptide Y family. J. Pept. Sci. 6, 97-122.

Cabrele, C., Wieland, H. A., Langer, M., Stidsen, C. E., and Beck-Sickinger, A. G. (2001). Y-receptor affinity modulation by the design of pancreatic polypeptide/neuropeptide $\mathrm{Y}$ chimera led to $\mathrm{Y}(5)$-receptor ligands with picomolar affinity. Peptides 22, 365-378. doi: 10.1016/S0196-9781(01)00339-4

Chin, J. W., Cropp, T. A., Anderson, J. C., Mukherji, M., Zhang, Z., and Schultz, P. G. (2003). An expanded eukaryotic genetic code. Science 301, 964-967. doi: $10.1126 /$ science. 1084772

Chin, J. W., Martin, A. B., King, D. S., Wang, L., and Schultz, P. G. (2002). Addition of a photocrosslinking amino acid to the genetic code of Escherichia
(031A239B), and the SMWK/SAB (100316655) is kindly acknowledged.

\section{ACKNOWLEDGMENTS}

We thank for the excellent technical support of Regina ReppichSacher (mass spectrometry), Kristin Löbner (cell culture), and Ronny Müller (peptide synthesis).

\section{SUPPLEMENTARY MATERIAL}

The Supplementary Material for this article can be found online at: https://www.frontiersin.org/articles/10.3389/fphar. 2019.00176/full\#supplementary-material

coli. Proc. Natl. Acad. Sci. U.S.A. 99, 11020-11024. doi: 10.1073/pnas.17222 6299

Corin, K., Baaske, P., Ravel, D. B., Song, J., Brown, E., Wang, X., et al. (2011a). A robust and rapid method of producing soluble, stable, and functional G-protein coupled receptors. PLoS One 6:e23036. doi: 10.1371/journal.pone. 0023036

Corin, K., Baaske, P., Ravel, D. B., Song, J., Brown, E., Wang, X., et al. (2011b). Designer lipid-like peptides: a class of detergents for studying functional olfactory receptors using commercial cell-free systems. PLoS One 6:e25067. doi: 10.1371/journal.pone.0025067

David, R., and Beck-Sickinger, A. G. (2007). Identification of the dimerisation interface of human interleukin- 8 by IL-8-variants containing the photoactivatable amino acid benzoyl-phenylalanine. Eur. Biophys. J. 36, 385-391. doi: 10.1007/s00249-006-0100-8

DeCarr, L. B., Buckholz, T. M., Coish, P. D., Fathi, Z., Fisk, S. E., Mays, M. R., et al. (2007). Identification of selective neuropeptide Y2 peptide agonists. Bioorg. Med. Chem.Lett. 17, 538-541. doi: 10.1016/j.bmcl.2006.10.007

Dehling, E., Volkmann, G., Matern, J. C., Dorner, W., Alfermann, J., Diecker, J., et al. (2016). Mapping of the communication-mediating interface in nonribosomal peptide synthetases using a genetically encoded photocrosslinker supports an upside-down helix-hand motif. J. Mol. Biol. 428, 4345-4360. doi: 10.1016/j.jmb.2016.09.007

Dormán, G., and Prestwich, G. D. (1994). Benzophenone photophores in biochemistry. Biochemistry 33, 5661-5573. doi: 10.1021/bi00185a001

Duarte-Neves, J., Pereira, de Almeida, L., and Cavadas, C. (2016). Neuropeptide Y (NPY) as a therapeutic target for neurodegenerative diseases. Neurobiol. Dis. 95, 210-224. doi: 10.1016/j.nbd.2016.07.022

Dundas, C. M., Demonte, D., and Park, S. (2013). Streptavidin-biotin technology: improvements and innovations in chemical and biological applications. Appl. Microbiol. Biotechnol. 97, 9343-9353. doi: 10.1007/s00253-013-5232-z

Gøtzsche, C. R., and Woldbye, D. P. (2016). The role of NPY in learning and memory. Neuropeptides 55, 79-89. doi: 10.1016/j.npep.2015.09.010

Hage, C., Iacobucci, C., Rehkamp, A., Arlt, C., and Sinz, A. (2017). The first zerolength mass spectrometry-cleavable cross-linker for protein structure analysis. Angew. Chem. Int. Ed. Engl. 56, 14551-14555. doi: 10.1002/anie.201708273

Hino, N., Okazaki, Y., Kobayashi, T., Hayashi, A., Sakamoto, K., and Yokoyama, S. (2005). Protein photo-cross-linking in mammalian cells by site-specific incorporation of a photoreactive amino acid. Nat. Methods 2, 201-206. doi: 10.1038/nmeth739

Hoffmann, B., Löhr, F., Laguerre, A., Bernhard, F., and Dötsch, V. (2018). Protein labeling strategies for liquid-state NMR spectroscopy using cell-free synthesis. Prog. Nucl. Magn. Reson. Spectrosc. 105, 1-22. doi: 10.1016/j.pnmrs.2017. 11.004

Hong, S. H., Kwon, Y. C., and Jewett, M. C. (2014). Non-standard amino acid incorporation into proteins using Escherichia coli cell-free protein synthesis. Front. Chem. 2:34. doi: 10.3389/fchem.2014.00034 
Isaksson, L., Enberg, J., Neutze, R., Göran Karlsson, B., and Pedersen, A. (2012). Expression screening of membrane proteins with cell-free protein synthesis. Protein Expr. Purif. 82, 218-225. doi: 10.1016/j.pep.2012.01.003

Ishihara, G., Goto, M., Saeki, M., Ito, K., Hori, T., Kigawa, T., et al. (2005). Expression of $\mathrm{G}$ protein coupled receptors in a cell-free translational system using detergents and thioredoxin-fusion vectors. Protein Expr. Purif. 41, 27-37. doi: $10.1016 /$ j.pep.2005.01.013

Junge, F., Haberstock, S., Roos, C., Stefer, S., Proverbio, D., Dötsch, V., et al. (2011). Advances in cell-free protein synthesis for the functional and structural analysis of membrane proteins. N. Biotechnol. 28, 262-271. doi: 10.1016/j.nbt.2010. 07.002

Kaiser, A., Hempel, C., Wanka, L., Schubert, M., Hamm, H. E., and Beck-Sickinger, A. G. (2018). G protein preassembly rescues efficacy of W6.48 toggle mutations in neuropeptide Y2 receptor. Mol. Pharmacol. 93, 387-401. doi: 10.1124/mol. 117.110544

Kaiser, A., Müller, P., Zellmann, T., Scheidt, H. A., Thomas, L., Bosse, M., et al. (2015). Unwinding of the $\mathrm{C}$-terminal residues of neuropeptide $\mathrm{Y}$ is critical for $\mathrm{Y}(2)$ receptor binding and activation. Angew. Chem. Int. Ed. Engl. 54, 7446-7449. doi: 10.1002/anie.201411688

Kashiwagi, K., Takahashi, M., Nishimoto, M., Hiyama, T. B., Higo, T., Umehara, T., et al. (2016). Crystal structure of eukaryotic translation initiation factor 2B. Nature 531, 122-125. doi: 10.1038/nature16991

Katritch, V., Cherezov, V., and Stevens, R. C. (2013). Structure-function of the G protein-coupled receptor superfamily. Annu. Rev. Pharmacol. Toxicol. 53, 531-556. doi: 10.1146/annurev-pharmtox-032112-135923

Kauer, J. C., Erickson-Viitanen, S., Wolfe, H. R. Jr., and DeGrado, W. F. (1986). p-Benzoyl-L-phenylalanine, a new photoreactive amino acid. Photolabeling of calmodulin with a synthetic calmodulin-binding peptide. J. Biol. Chem. 261, 10695-10700.

Kirby, D. A., Koerber, S. C., Craig, A. G., Feinstein, R. D., Delmas, L., Brown, M. R., et al. (1993). Defining structural requirements for neuropeptide Y receptors using truncated and conformationally restricted analogues. J. Med. Chem. 36, 385-393. doi: 10.1021/jm00055a010

Klammt, C., Schwarz, D., Eifler, N., Engel, A., Piehler, J., Haase, W., et al. (2007). Cell-free production of G protein-coupled receptors for functional and structural studies. J. Struct. Biol. 158, 482-493. doi: 10.1016/j.jsb.2007.01.006

Klammt, C., Schwarz, D., Fendler, K., Haase, W., Dötsch, V., and Bernhard, F. (2005). Evaluation of detergents for the soluble expression of alpha-helical and beta-barrel-type integral membrane proteins by a preparative scale individual cell-free expression system. FEBS J. 272, 6024-6038. doi: 10.1111/j.1742-4658. 2005.05002.x

Kostenis, E. (2001). Is Galpha16 the optimal tool for fishing ligands of orphan G-protein-coupled receptors? Trends Pharmacol. Sci. 22, 560-564.

Latorraca, N. R., Venkatakrishnan, A. J., and Dror, R. O. (2017). GPCR dynamics: structures in motion. Chem. Rev. 117, 139-155. doi: 10.1021/acs.chemrev. $6 \mathrm{~b} 00177$

Lee, K. H., Kwon, Y. C., Yoo, S. J., and Kim, D. M. (2010). Ribosomal synthesis and in situ isolation of peptide molecules in a cell-free translation system. Protein Expr. Purif. 71, 16-20. doi: 10.1016/j.pep.2010.01.016

Lee, Y., Basith, S., and Choi, S. (2018). Recent advances in structure-based drug design targeting class A G protein-coupled receptors utilizing crystal structures and computational simulations. J. Med. Chem. 61, 1-46. doi: 10.1021/acs. jmedchem.6b01453

Lerch, M., Gafner, V., Bader, R., Christen, B., Folkers, G., and Zerbe, O. (2002). Bovine pancreatic polypeptide (bPP) undergoes significant changes in conformation and dynamics upon binding to DPC micelles. J. Mol. Biol. 322, 1117-1133. doi: 10.1016/S0022-2836(02)00889-6

Lerch, M., Mayrhofer, M., and Zerbe, O. (2004). Structural similarities of micellebound peptide YY (PYY) and neuropeptide Y (NPY) are related to their affinity profiles at the Y receptors. J. Mol. Biol. 339, 1153-1168. doi: 10.1016/j.jmb.2004. 04.032

Li, J., Tian, Y., and Wu, A. (2015). Neuropeptide Y receptors: a promising target for cancer imaging and therapy. Regen. Biomater. 2, 215-219. doi: 10.1093/rb/ rbv013

Lindner, D., Walther, C., Tennemann, A., and Beck-Sickinger, A. G. (2009). Functional role of the extracellular N-terminal domain of neuropeptide $\mathrm{Y}$ subfamily receptors in membrane integration and agonist-stimulated internalization. Cell. Signal. 21, 61-68. doi: 10.1016/j.cellsig.2008.09.007
Madshus, I. H. (1988). Regulation of intracellular pH in eukaryotic cells. Biochem. J. 250, 1-8. doi: 10.1042/bj2500001

Manglik, A., Kim, T. H., Masureel, M., Altenbach, C., Yang, Z., Hilger, D., et al. (2015). Structural insights into the dynamic process of beta2adrenergic receptor signaling. Cell 161, 1101-1111. doi: 10.1016/j.cell.2015. 04.043

Merten, N., Lindner, D., Rabe, N., Römpler, H., Mörl, K., Schöneberg, T., et al. (2007). Receptor subtype-specific docking of Asp6.59 with C-terminal arginine residues in Y receptor ligands. J. Biol. Chem. 282, 7543-7551. doi: 10.1074/jbc. M608902200

Michel, E., and Wüthrich, K. (2012). Cell-free expression of disulfide-containing eukaryotic proteins for structural biology. FEBS J. 279, 3176-3184. doi: 10.1111/ j.1742-4658.2012.08697.x

Nguyen, T. A., Cigler, M., and Lang, K. (2018). Expanding the genetic code to study protein-protein interactions. Angew. Chem. Int. Ed. Engl. 57, 14350-14361. doi: 10.1002/anie.201805869

Orban, E., Proverbio, D., Haberstock, S., Dötsch, V., and Bernhard, F. (2015). Cell-free expression of G-protein-coupled receptors. Methods Mol. Biol. 1261, 171-195. doi: 10.1007/978-1-4939-2230-7_10

Orth, J. H., Schorch, B., Boundy, S., Ffrench-Constant, R., Kubick, S., and Aktories, K. (2011). Cell-free synthesis and characterization of a novel cytotoxic pierisin-like protein from the cabbage butterfly Pieris rapae. Toxicon 57, 199-207. doi: 10.1016/j.toxicon.2010.11.011

Pedragosa-Badia, X., Sliwoski, G. R., Dong Nguyen, E., Lindner, D., Stichel, J., Kaufmann, K. W., et al. (2014). Pancreatic polypeptide is recognized by two hydrophobic domains of the human Y4 receptor binding pocket. J. Biol. Chem. 289, 5846-5859. doi: 10.1074/jbc.M113.502021

Pedragosa-Badia, X., Stichel, J., and Beck-Sickinger, A. G. (2013). Neuropeptide Y receptors: how to get subtype selectivity. Front. Endocrinol. (Lausanne) 4:5. doi: $10.3389 /$ fendo.2013.00005

Preston, G. W., and Wilson, A. J. (2013). Photo-induced covalent cross-linking for the analysis of biomolecular interactions. Chem. Soc. Rev. 42, 3289-3301. doi: $10.1039 / \mathrm{c} 3 \operatorname{cs} 35459 \mathrm{~h}$

Proverbio, D., Roos, C., Beyermann, M., Orbán, E., Dötsch, V., and Bernhard, F. (2013). Functional properties of cell-free expressed human endothelin A and endothelin B receptors in artificial membrane environments. Biochim. Biophys. Acta 1828, 2182-2192. doi: 10.1016/j.bbamem.2013.05.031

Reichmann, F., and Holzer, P. (2016). Neuropeptide Y: a stressful review. Neuropeptides 55, 99-109. doi: 10.1016/j.npep.2015.09.008

Robinson, S. L., and Thiele, T. E. (2017). The role of neuropeptide Y (NPY) in alcohol and drug abuse disorders. Int. Rev. Neurobiol. 136, 177-197. doi: 10.1016/bs.irn.2017.06.005

Roy, A., Shukla, A. K., Haase, W., and Michel, H. (2008). Employing Rhodobacter sphaeroides to functionally express and purify human $\mathrm{G}$ protein-coupled receptors. Biol. Chem. 389, 69-78. doi: 10.1515/BC.2008.001

Schmidt, P., Bender, B. J., Kaiser, A., Gulati, K., Scheidt, H. A., Hamm, H. E., et al. (2017). Improved in vitro folding of the Y2 G protein-coupled receptor into bicelles. Front. Mol. Biosci. 4:100. doi: 10.3389/fmolb.2017. 00100

Schmidt, P., Lindner, D., Montag, C., Berndt, S., Beck-Sickinger, A. G., Rudolph, R., et al. (2009). Prokaryotic expression, in vitro folding, and molecular pharmacological characterization of the neuropeptide Y receptor type 2. Biotechnol. Prog. 25, 1732-1739. doi: 10.1002/ btpr.266

Schwarz, D., Junge, F., Durst, F., Frölich, N., Schneider, B., Reckel, S., et al. (2007). Preparative scale expression of membrane proteins in Escherichia coli-based continuous exchange cell-free systems. Nat. Protoc. 2, 2945-2957. doi: 10.1038/ nprot.2007.426

Seidel, L., and Coin, I. (2018). Mapping of protein interfaces in live cells using genetically encoded crosslinkers. Methods Mol. Biol. 1728, 221-235. doi: 10. 1007/978-1-4939-7574-7_14

Shimamura, T., Shiroishi, M., Weyand, S., Tsujimoto, H., Winter, G., Katritch, V., et al. (2011). Structure of the human histamine H1 receptor complex with doxepin. Nature 475, 65-70. doi: 10.1038/nature10236

Shukla, A. K., Kumari, P., Ghosh, E., and Nidhi, K. (2015). From recombinant expression to crystals: a step-by-step guide to GPCR crystallography. Methods Enzymol. 556, 549-561. doi: 10.1016/bs.mie.2015. 01.017 
Sinz, A. (2006). Chemical cross-linking and mass spectrometry to map three-dimensional protein structures and protein-protein interactions. Mass Spectrom. Rev. 25, 663-682. doi: 10.1002/mas.20082

Sinz, A. (2017). Divide and conquer: cleavable cross-linkers to study protein conformation and protein-protein interactions. Anal. Bioanal. Chem. 409, 33-44. doi: 10.1007/s00216-016-9941-x

Sinz, A. (2018). Cross-linking/mass spectrometry for studying protein structures and protein-protein interactions: where are we now and where should we Go from here? Angew. Chem. Int. Ed. Engl. 57, 6390-6396. doi: 10.1002/anie. 201709559

Smith, E., and Collins, I. (2015). Photoaffinity labeling in target- and binding-site identification. Future Med. Chem. 7, 159-183. doi: 10.4155/fmc.14.152

Sriram, K., and Insel, P. A. (2018). G protein-coupled receptors as targets for approved drugs: how many targets and how many drugs? Mol. Pharmacol. 93, 251-258. doi: 10.1124/mol.117.111062

Staunton, D., Schlinkert, R., Zanetti, G., Colebrook, S. A., and Campbell, I. D. (2006). Cell-free expression and selective isotope labelling in protein NMR. Magn. Reson. Chem. 44 Spec No, S2-A9. doi: 10.1002/mrc.1835

Su, X. C., Loh, C. T., Qi, R., and Otting, G. (2011). Suppression of isotope scrambling in cell-free protein synthesis by broadband inhibition of PLP enymes for selective $15 \mathrm{~N}$-labelling and production of perdeuterated proteins in $\mathrm{H}_{2}$ O. J. Biomol. NMR 50, 35-42. doi: 10.1007/s10858-011-9477-5

Suchanek, M., Radzikowska, A., and Thiele, C. (2005). Photo-leucine and photomethionine allow identification of protein-protein interactions in living cells. Nat. Methods 2, 261-267. doi: 10.1038/nmeth752

Sumranjit, J., and Chung, S. J. (2013). Recent advances in target characterization and identification by photoaffinity probes. Molecules 18, 10425-10451. doi: 10.3390/molecules180910425

Tan, C. M. J., Green, P., Tapoulal, N., Lewandowski, A. J., Leeson, P., and Herring, N. (2018). The role of neuropeptide $Y$ in cardiovascular health and disease. Front. Physiol. 9:1281. doi: 10.3389/fphys.2018.01281

Tapaneeyakorn, S., Ross, S., Attrill, H., and Watts, A. (2010). Heterologous high yield expression and purification of neurotensin and its functional fragment in Escherichia coli. Protein Expr. Purif. 74, 65-68. doi: 10.1016/j.pep.2010.06.014

Thomas, L., Scheidt, H. A., Bettio, A., Beck-Sickinger, A. G., Huster, D., and Zschörnig, O. (2009). The interaction of neuropeptide Y with negatively charged and zwitterionic phospholipid membranes. Eur. Biophys. J. 38, 663-677. doi: 10.1007/s00249-009-0423-3

Thomas, L., Scheidt, H. A., Bettio, A., Huster, D., Beck-Sickinger, A. G., Arnold, K., et al. (2005). Membrane interaction of neuropeptide Y detected by EPR and NMR spectroscopy. Biochim. Biophys. Acta 1714, 103-113. doi: 10.1016/j. bbamem.2005.06.012

Tilan, J., and Kitlinska, J. (2016). Neuropeptide Y (NPY) in tumor growth and progression: lessons learned from pediatric oncology. Neuropeptides 55, 55-66. doi: $10.1016 /$ j.npep.2015.10.005

Tsuboi, T., Takeo, S., Sawasaki, T., Torii, M., and Endo, Y. (2010). An efficient approach to the production of vaccines against the malaria parasite. Methods Mol. Biol. 607, 73-83. doi: 10.1007/978-1-60327-331-2_8
Tucker, J., and Grisshammer, R. (1996). Purification of a rat neurotensin receptor expressed in Escherichia coli. Biochem. J. 317, 891-899.

Venkatakrishnan, A. J., Deupi, X., Lebon, G., Tate, C. G., Schertler, G. F., and Babu, M. M. (2013). Molecular signatures of G-protein-coupled receptors. Nature 494, 185-194. doi: 10.1038/nature11896

Villate, M., Merino, N., and Blanco, F. J. (2012). Production of meganucleases by cell-free protein synthesis for functional and structural studies. Protein Exp. Purif. 85, 246-249. doi: 10.1016/j.pep.2012.07.013

Wang, X., Cui, Y., and Wang, J. (2013). Efficient expression and immunoaffinity purification of human trace amine-associated receptor 5 from E. coli cell-free system. Protein Pept. Lett. 20, 473-480. doi: 10.2174/0929866511320040012

Wanka, L., Babilon, S., Kaiser, A., Mörl, K., and Beck-Sickinger, A. G. (2018). Different mode of arrestin-3 binding at the human Y1 and Y2 receptor. Cell. Signal. 50, 58-71. doi: 10.1016/j.cellsig.2018.06.010

Weber, P. J., and Beck-Sickinger, A. G. (1997). Comparison of the photochemical behavior of four different photoactivatable probes. J. Pept. Res. 49, 375-383. doi: 10.1111/j.1399-3011.1997.tb00889.x

Wilchek, M., and Bayer, E. A. (1988). The avidin-biotin complex in bioanalytical applications. Anal. Biochem. 171, 1-32. doi: 10.1016/0003-2697(88)90120-0

Wilkins, M. R., Lindskog, I., Gasteiger, E., Bairoch, A., Sanchez, J. C., Hochstrasser, D. F., et al. (1997). Detailed peptide characterization using PEPTIDEMASS-a world-wide-web-accessible tool. Electrophoresis 18, 403-408. doi: 10.1002/elps. 1150180314

Witte, K., Kaiser, A., Schmidt, P., Splith, V., Thomas, L., Berndt, S., et al. (2013). Oxidative in vitro folding of a cysteine deficient variant of the $\mathrm{G}$ protein-coupled neuropeptide $\mathrm{Y}$ receptor type 2 improves stability at high concentration. Biol. Chem. 394, 1045-1056. doi: 10.1515/hsz-20130120

Xiang, J., Chun, E., Liu, C., Jing, L., Al-Sahouri, Z., Zhu, L., et al. (2016). Successful strategies to determine high-resolution structures of GPCRs. Trends Pharmacol. Sci. 37, 1055-1069. doi: 10.1016/j.tips.2016.09.009

Yang, Z., Han, S., Keller, M., Kaiser, A., Bender, B. J., Bosse, M., et al. (2018). Structural basis of ligand binding modes at the neuropeptide Y Y1 receptor. Nature 556, 520-524. doi: 10.1038/s41586-018-0046-x

Yi, M., Li, H., Wu, Z., Yan, J., Liu, Q., Ou, C., et al. (2018). A promising therapeutic target for metabolic diseases: neuropeptide Y receptors in humans. Cell. Physiol. Biochem. 45, 88-107. doi: 10.1159/000486225

Conflict of Interest Statement: The authors declare that the research was conducted in the absence of any commercial or financial relationships that could be construed as a potential conflict of interest.

Copyright (c) 2019 Kögler, Stichel, Kaiser and Beck-Sickinger. This is an open-access article distributed under the terms of the Creative Commons Attribution License (CC BY). The use, distribution or reproduction in other forums is permitted, provided the original author(s) and the copyright owner(s) are credited and that the original publication in this journal is cited, in accordance with accepted academic practice. No use, distribution or reproduction is permitted which does not comply with these terms. 